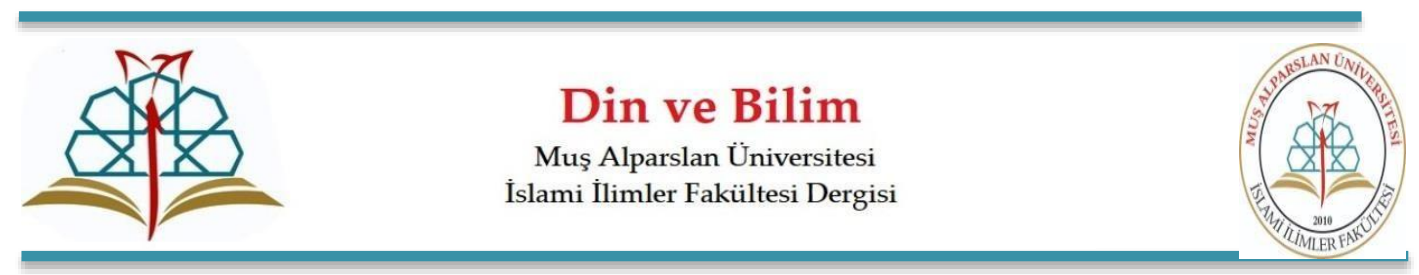

Din ve Bilim - Muş Alparslan Üniversitesi İslami İlimler Fakültesi Dergisi Region and Science - Journal of Muş Alparslan University Faculty of Islamic Sciences e-ISSN: 2667-7717 Haziran/June 2021, 4(1): 71-96

\title{
İslam Hukuku ve Uluslararası Hukukta Esir Hakları
}

Right of Prisoners in Islamic and International Law

\section{Fawaz Mohammed ABDO ALi}

Doktora Öğrencisi, Necmettin Erbakan Üniversitesi, Sosyal Bilimler Enstitüsü,

Temel İslam Bilimleri Anabilim Dalı

PhD. Student, Necmettin Erbakan University, Social Sciences Institute,

Department of Basic Islamic Sciences

Konya/Turkey

fawaz20833@gmail.com

ORCID: 0000-0003-4308-2299

\section{Makale Bilgisi I Article Information}

Makale Türü / Article Type: Araştırma Makalesi / Research Article

Geliş Tarihi / Date Received: 01 Mayıs / May 2021

Kabul Tarihi / Date Accepted: 11 Haziran / June 2021

Yayın Tarihi / Date Published: 30 Haziran / June 2021

Yayın Sezonu / Pub Date Season: Haziran / June

DOI: $10.47145 /$ dinbil.930781

Atıf / Citation: Abdo Ali, Fawaz Mohammed. "İslam Hukuku ve Uluslararası Hukukta Esir Hakları / Right of Prisoners in Islamic and International Law". Din ve Bilim Muş Alparslan Üniversitesi İslami İlimler Fakültesi Dergisi 4 / 1 (Haziran 2021): 71-96. doi:

\subsection{5/dinbil.930781}

İntihal: Bu makale, iThenticate yazılımınca taranmıştır. İntihal tespit edilmemiştir.

Plagiarism: This article has been scanned by iThenticate. No plagiarism detected. web: https://dergipark.org.tr/tr/pub/dinbil I mailto: dinbil@alparslan.edu.tr

Copyright @ Published by Muş Alparslan Üniversitesi, İslami İlimler Fakültesi / Muş Alparslan University, Faculty of Islamic Sciences, Muş, 49250 Turkey.

Bütün hakları saklıdır. / All right reserved. 


\title{
Öz
}

İslam fıkhının tarih sürecine dahil oluşundan beri en önemli yanlarından biri haklar konusudur. Özellikle savaş ve barış zamanlarında insan hakları fıkıh literatüründe büyük bir yer kaplamıştır. İnsan, savaş sırasında özgürlüğünü kaybedebilir, zulüm ve kötü muamele görebilir veya hapse atılabilir. Bu nedenle, İslam esirlere iyi davranılması hususunda dikkate alınması gereken hak, görev ve kurallar belirlemiştir. Tarihe bakacak olursak esirlere yönelik tasarruflar konusunda karanlık uygulamalara rastlamaktayız. Çünkü esirlerin düşman elinde kaldığı sürece insan değerlerini ihlal eden muamelelerle karşılaştığı̆, dövme, yaralama, taciz, yakma gibi fiziksel işkenceye maruz kaldığını görebilmekteyiz. Yine esirin yeme ve içmeden mahrum bırakılarak, açlık ve susuzlukla cezalandırılıp ölüme terkedildiğini İslam öncesi cahiliye dönemi uygulamalarından anlamaktayız. Esirler konusunda gerek İslam hukukunda gerekse sivil hukukta çeşitli maddeler ve hükümler benimsenmiştir. İslam hukuku bağlamında esirlerin takas edilmesi ve öldürülmesine ilişkin farklı görüşler ortaya konmuştur. Fıkıh ekolleri arasında onların öldürülmesini yanlış bulanlar olduğu gibi konuyu ülkenin çıkarı bağlamında değerlendirenlere de rastlanmıştır. Çalışmamızda İslam hukukunda konuya ilişkin tartışmaları bir nebze aydınlatmak gayesi güdülmüş, yürürlükteki uluslararası antlaşmaların savaşlardaki tutsak hukukuna ilişkin atıflarına değinilmiştir.

Anahtar Kelimeler: İslam Hukuku, Esir, Haklar, Hukuk, Uluslararası Hukuk

\begin{abstract}
One of the most important aspects of Islamic fiqh since its inclusion in the historical process is the issue of rights. Especially in times of war and peace, human rights have an important place in the fiqh literature. During war, man can lose his freedom, be persecuted, mistreated or imprisoned. For this reason, Islam has determined the rights, duties and rules that should be taken into account regarding the good treatment of captives. If we look at history, we come across dark practices regarding savings for captives. Because we can see that the prisoners are subjected to physical torture such as beating, wounding, harassment and burning as long as they remain in the hands of the enemy. Again, we understand from the practices of the pre-Islamic period of Jahiliyyah that the prisoner was deprived of eating and drinking, punished with hunger and thirst, and left to die. In both Islamic law and civil law, various articles and provisions have been adopted on the subject of captives. In the context of Islamic law, different views have been put forward regarding the exchange and killing of prisoners. Among the schools of fiqh, there are those who find their killing wrong, as well as those who evaluate the issue in the context of the country's interest. In our study, it is aimed to illuminate the discussions on the subject in Islamic law to some extent, and the references of the current international treaties to the prisoner law in wars are mentioned.
\end{abstract}

Keywords: Islamic Law, Captive, Rights, Law, International Law 


\section{Giriş}

İslam'la birlikte ortaya konan şerî hükümler veya başka bir ifadeyle İslam hukuku kuralları; güvenlik, adalet ve merhameti sağlayarak esirlere karşı davranışı insanlık şeref ve haysiyetini gözeten haklarla korumayı amaçlamış, insanî ve vicdanî bir çerçevede önemli prensipler getirmiştir. Kur'an-ı Kerim'de esir haklarını vurgulamak amacıyla esirlere iyi davranmanın Allah rızasını kazanmayı ve cennetine girmeyi gerektirecek bir davranış olduğu ve müminlerin özelliklerinden biri olduğu bildirilmiştir. "Onlar, seve seve yiyeceği yoksula, yetime ve esire yedirirler. (Yedirdikleri kimselere şöyle derler) "Biz size sırf Allah rızası için yediriyoruz. Sizden bir karşıllı ve bir teşekkür beklemiyoruz."1

Yüzyıllardır entelektüeller ve düşünürler insanoğlunu ilgilendiren en önemli konulardan biri sayılan esirler meselesiyle meşgul olmuştur. Sesli, görsel ve basılı medyada esirliğe dair tartışmalar büyük bir yer kaplamıştır. Zira bu meselede her asırda olduğu gibi zamanımızda da savaşla ilgili bazı esirlik/tutsaklık hallerinin varlığı, haksız uygulamaların mevcudiyeti nedeniyle İslam hukukçuları ve insan bilimleri uzmanlarının geniş araştırmalarına ihtiyaç duyulmaktadır. Meselenin bazı yönleri geçmişten günümüze fakihler tarafından ele alınmış olsa da uluslararası yasalarla da karşılaştırılarak daha geniş bir yelpazede ele alınıp ona dair daha kapsamlı bir yaklaşım geliştirilmesi gerekmektedir.

Esirler ve esir haklarına ilişkin birçok hükme, fetvaya ve maddeye rastlamak mümkündür. Ancak bahsedilen maddelerin çoğu fıkıh kitaplarında ayrı ve müstakil bir bölümde ele alınmamakta, farklı kitaplarda dağınık halde bulunmaktadır. İslam hukukunda belirlenen esir haklarının insan ilişkilerini düzenleyen uluslararası hukukla karşılaştırılarak bağımsız bir araştırma yapılması uygun olacaktır. Aslında seküler hukukta insanî standartlar ve örfî birtakım kurallar yasa haline getirilip esirler konusu bir yönüyle şekillendirilmiştir. Fakat insanları din konusunda aydınlatmak için meseleye İslam hukuku açısından yaklaşmak da gereklidir.

Bu konuyu seçme sebepleri hakkında şu hususları belirtmek mümkündür:

Birçok ülke, esir hakları konusunda aralarında ittifak ettikleri uluslararası hukuku uygulamayı başaramamıştır. Söz gelimi Guantanamo ve İsrail hapishanelerinde Müslüman esirlere sert bir şekilde davranıldığı kaydedilmiştir. Devlet yetkililerinin çıkardığı yasaları yok sayıp esirleri acımasızca işkencelere maruz bırakarak ölüme terkettikleri bir gerçektir. Dünyanın değişik yerlerinde farklı din ve soylardan esirlerin akıl dişı her türlü işkenceye tabi tutulduğuna ve en basit haklardan nasıl mahrum bırakıldığına her gün şahit olunmaktadır.

$\mathrm{Bu}$ bağlamda İslam'ın esirlere verdiği hakları ortaya koyup uluslararası hukukla da ilişkilendirecek düşünce ve çözümlere son derece ihtiyaç duymaktayız. Çalışmamızla uluslararası ilişkiler bağlamında önemli bir mesele olan esirler meselesinde derli toplu, kapsamlı ve bağımsız bir araştırma ortaya koymak, İslamî çalışmalar literatürünü zenginleştirmek istenmiştir. Esirlerin hakları meselesinde Batı düşüncesi ile İslam düşüncesi arasındaki benzerlik ve farklılıkları ortaya koymak amaçlanmıştır. İnsanoğlu tarafından konulmuş olan uluslararası hukukun, ilahi yasaları yansıtan İslam fıkhı ile karşılaştırıldığında kusurlu ve yetersiz kalacağı yönler olması muhtemeldir. Bununla birlikte yanlış İslami yorumların da hukuk algısına zarar vereceği unutulmamalıdır.

$\mathrm{Bu}$ araştırmada aşağıdaki metotlar izlenmekte, tümevarımlı ve analitik bir yaklaşım kullanılmaktadır. Kur'an ayetlerine atıfta bulunulmuş, gerekirse de anlamları açığa kavuşturulmuş, hadis-i şeriflerin tahriç ve değerlendirilmesi gerçekleştirilmiştir. Mezheplerin farklı fıkhî görüşleri,

\footnotetext{
1 el-İnsân 76/9-8.
} 
kaynaklarıyla sunulmuştur. Bazı meselelerde ise fakihlerin farklı görüşlerini tartışmaya açmadan kısaca aktarmakla yetinilmiştir. İslam hukuku karşılaştırılmıştır.

Esir hakları, İslam fıkhının önemli konularından biri olduğundan geçmişten günümüze başta meşhur mezhepler olmak üzere bütün fakihler tarafından farklı kitaplarda ele alınmıştır. Ayrıca Buhârî (ö. 256/870), Müslim (ö.261/875), Ebu Dâvûd (ö. 275/889) ve Heysemî ( ö. 807/1405) gibi muhaddislerin yazdığı risale ve kitaplarda "esir" ve "cihâd" gibi ayrı bâblarda işlenmiştir. Buna ek olarak, İslam Tarihi Siret-i İbn-i Hişam, İbn Şihab ez-Zührî'nin (ö.124/742) el-Meğâzî en-Nebeviyye adlı eseri, el-Vakıdî'nin (ö. 207/823) el-Meğâzzî adlı eseri ve el-Halebî'nin (ö. 1044/1635) es-Sîretü'l-Halebiyye adlı eseri gibi siyer kaynakları da konuya değinmiştir. Ancak bu kitaplarda yer alan bilgileri toplayıp derli toplu bir şekilde konunun özünü ortaya koymak gerekmektedir.

Çağımız ulemasından Muhammed Ebu Zehra (ö. 1394/1974), 1958 yılında yayımladığı “Nazariyyetu'l-Harb fi'l-İslam” (İslam'da Savaş Teorisi) adlı makalesiyle konuyu ele alan ilk çağdaş yazarlardan biri olmuştur.

Vehbe Zuhaylî'nin (ö.1436/2015) el-Alakatü'd-düveliyye fi'l-İslam mukareneten bi'l-kânuni'ddüveliyyi'l-hadîs isimli kitabı, Yûsuf el-Karadâvî'nin Fıkhu'l-cihâdadlı eseri, Ali Tayyâr'ın Adabu'l-harb fi'l-fikhi'l-İslamî ve'l-kânûni'd-düvelî başlıklı çalışması, Halid el-Bedaye'nin Savaş Suçları adlı kitabı gibi çağdaş yazıların da İslam hukukunda esirler meselesinin ele alınmasına çok faydası olmuştur.

Böylelikle uluslararası kamu hukuku alanındaki İslami araştırmalardan da yola çıkarak İslam hukukunda ve uluslararası hukukta esirlerin hakları konusu bu araştırmamızda karşılaştırmalı bir şekilde ele alınacaktır.

\section{1. İslam Öncesi Arap Toplumu ve Farklı Milletler ile İslam’a Göre Esir Haklarına Genel Bakış}

İslam öncesinde bazı toplumlarda esirlere sert davranılmış, öldürülmüş ve beden bütünlüğüne zarar verilmiştir. Esirler, düşman eline düştüğünde gözlerine mil çekilme veya el ve bacaklarının kesilmesi gibi çeşitli barbarca işkencelere maruz kalmışlardır. ${ }^{2}$

Yahudi kanunu Talmud'a göre; hayvan, çocuk ve kadınlar dahil olmak üzere bütün esirler öldürülmelidir. İslam öncesi Cahiliye Arap toplumunda esirler boğazlanıp tanrılara kurban olarak takdim edilmiş, panayırlarda köle olarak alınıp satılmıştır. Diğer taraftan Persler ve Yunanlılar da esirlerine o kadar acımasızca davranmışlar, onları çarmıha gerip işkence, ölüm ve eziyete maruz bırakmışlardır. Araplar da komşularının alışkanlıklarından etkilenerek esirlerine insanlık ve merhametten yoksun bir şekilde yaklaşmışlardır. ${ }^{3}$

Cahiliye döneminin son zamanlarında ise esirler, öldürülmek yerine köle olarak kullanılmaya başlanmıştır. Böylelikle köleliğin meşruiyeti, insan veya eşya olmasına bakılmaksızın savaşta eline düşen her şeye sahip olma hakkı veren eski savaş ilkelerinden kaynaklanmıştır. ${ }^{4}$

Günümüzde ise esirler meselesi, medeniyet ve uygarlık çağının temel sorunlarından biri olma durumunu korumaktadır. Uluslararası hukuk bulunduğu halde bu hukukun gereklilikleri yerine getirilmemektedir. Konuyla ilgili sivil yasaları ve dinî hükümleri bilmeyen yoktur. Ne var ki kimse bu

\footnotetext{
2 Abdulvahid Muhammed Yusuf el-Far, Esru'l-harb (Kahire: Alemü'l-Kütübi'l-Kâhire, 1975), 117.

${ }^{3}$ Vehbe ez-Zühaylî, Âsâru'l-harbi fi'l-fikhi'l-İslâmî (Dımaşk: Daru'l-Fikr, 1998), 404.

${ }^{4}$ Ali Tayyâr, Âdâbu'l-harb fi'l-fikhi'l-İslâmî (Riyad: Mektebetü'l-Melik Fehd, 2008), 118.
} 
hak ve sistemlere önem vermemektedir. Tam tersine gücü tekelinde bulunduranlar, zayıflara

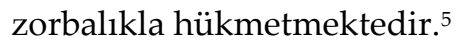

Etik ve ahlak, insanî değer ve ilkeler korunmamaktadır. Realitede utanç verici olaylarla karşılaşılmaktadır. Üstelik devletlerin ve hükümetlerin, yalnızca insan hakları ve özgürlükleri değil, bunlara ek olarak hayvan haklarını da savunduğunu iddia etmesine rağmen esirlere kötü şekilde davranılmasını görmezden gelmeleri büyük bir tezat oluşturmaktadır.

Kur'an-1 Kerim'in çok sayıda ayeti ve birçok hadis, esirlerin insana layık ve iyi bir şekilde davranılmasından bahsetmiştir. Yüce Allah Enfâl Suresi'nde şöyle buyurmaktadır: “Ey Peygamber! Elinizdeki esirlere söyle: Ĕ̆ger Allah kalplerinizde iman, ihlas, iyi niyet gibi bir hayır olduğunu bilirse sizden alınan fidyeden daha hayırlısını size verir ve sizi bağışlar. Allah çok bağışlayandır, çok merhamet edendir." 6 Yüce Allah'ın kalplerinde hayır var olan esirleri bağışlayacağına ve merhamet edeceğine söz verdiğine göre Müslümanlar da artık esirlere ancak insanlık ve merhametle dolu bir şekilde davranmalıdır.

İslam hukukuna göre Müslümanların, esirleri aç bırakmaması gerekmektedir. Üstelik esirlerin yemekleri, müslümanların yemeklerine nicelik ve nitelik açısından benzer veya mümkünse onlardan daha iyi olmalıdır. Çünkü yüce Allah şöyle buyurmuştur: "Onlar, seve seve yiyeceği yoksula, yetime ve esire yedirirler." ${ }^{\prime}$ Ebu Aziz b. Umeyr'in -Bedir esirlerinden bir şahıs- şöyle dediği rivayet edilmiştir: “Bedir muharebesinden döndügüumüzde Ashab-1 kiram Nebi'nin tavsiyesini yerine getirirek öğle ve akşam yemeğinde kendilerine takdim edilen hurmadan yerlerken bana ise esir olmama rağmen özellikle ekmek verilirdi. Öyle ki birisi bir ekmek parçası bulup bana getiridiğinde, ben de utandığımdan dolayı başkasına vermeye çalışırken hemen her defasında bana mani olur ve o ekmeği tekrar bana geri verirlerdi." ${ }^{8}$

Ayrıca İslam, lütuf, merhamet ve adaletiyle esirleri aşağılamadan ve hakaret etmeden onlara nezaketle davranılması gerektiğini söylemiştir. Taberânî (ö. 360/971) Ebu Hüreyre'den rivayetle Resulullah (s.a.v)'in şöyle buyurduğunu bildirir: "Kadınlara karşı hayırhah olun. Çünkü onlar sizin yanınızda esirler gibidirler. Onlara iyi davranmaktan başka bir hakkınız yoktur." ${ }^{9}$ Delillere göre esiri işkenceye maruz bırakmak hiçbir zaman caiz değildir.

\subsection{Esirin Lugat ve Istılah Manası}

Lugat manasi: Esir kelimesi zincir anlamına gelen isar kelimesinden türemiştir. Buradan yola çıkarak zamanla zincirlenen kimseye de esir denmiştir. Eski müfessirlerden Mücahid b. Cebr (ö. 103/721), el-İnsan Suresi 8. ayette geçen “Onlar, seve seve yiyeceği yoksula, yetime ve esire yedirirler" ifadesinin tefsirinde esirin, tutuklu anlamına geldiğini söylemiştir. ${ }^{10}$ Türkçede esir kelimesi yanında tutsak kelimesi de kullanılmaktadır.

\footnotetext{
${ }^{5}$ Tayyâr, Âdâbu'l-harb fi'l-fikhi'l-İslâmî, 181.

${ }^{6}$ el-Enfâl 8/70.

7 el-İnsân 76/8.

${ }^{8}$ Ebû Muhammed Cemâlüddîn İbn Hişâm, es-Sîretü'n-nebeviyye, thk. Mustafa es-Sakâ - İbrahim el-Eybârî (Beyrut: Daru'l-Hayr, 1996), 2/299; Alî b. Ebî Bekr el-Hisemî, Mecme'û'z-zevâid ve menbe'u'l-fevâid (Beyrut: Daru'l-kitâbi'l-Arabî, 1402), 6/89.

${ }^{9}$ el-Heysemî, Mecme' $\hat{u}^{\prime} z$-zevâid ve menbe'u'l-fevâid, 6/89.

${ }^{10}$ Ebü'l-Hasen Alî b. Muhammed b. Habîb el-Mâverdî, el-Ahkâmu's-sultaniyyetu ve'l-velâyetü'd-diniyye (Mısır: Mustafa'l-Babî'lHalabî, ts.), 167; Heyet, el-Mevsûatü'l-fikhiyye (Kuveyt: Evkafu'l-Kuveyt, ts.), 4/195.
} 
Istılah manası: el-Maverdi'ye (ö. 450/1058) göre esirler, müslümanların eline düşen kâfir erkek savaşçılarıdır. ${ }^{11}$

Uluslararası hukuka göre esir, savaş neticesinde düşmanın eline düşen-geçen kimsedir.

İslam hukuku esir kelimesini erkeklerle sinırlandırırken uluslararası hukuk bir cins belirtmemiştir. İslam hukuku esir kelimesini kafirlerle sınırlandırırken uluslararası hukuk esirin belli bir dine mensup olması gerektiğini vurgulamamıştır. ${ }^{12}$

\section{2. İslam Hukuku ve Uluslararası Hukukta Esir Almanın Meşruiyeti}

Hicretin ilk on yılından itibaren esir almanın meşru olduğu bildirilmiştir. Kur'an ve sünnetten esir almaya dair kullanılan bazı deliller şunlardır:

Kur'an'da şöyle buyrulmaktadır: "Savaşta inkâr edenlerle karşılaştığınız zaman hemen boyunlarını vurun. Nihayet onlara üstün geldiğiniz zaman bağı sıkı bağlayıp esir alın. Sonra harp ağırlıklarını atıp, savaş bitince de onlar ya karşılıksız olarak, ya da fidye ile salıverin. Allah'ın emri budur. Ĕ̆ger Allah dileseydi onlardan başka türlü de intikam alırdı. Fakat böyle olması sizi birbirinizle denemek içindir. Allah yolunda öldürülenlere gelince, Allah onların amellerini asla boşa çıkarmaz."13

İslam tarihinde Müslümanların savaşlarda düşmanların ve fethettiği ülkelerden halkın tamamını esir alma hadisesine rastlanmamıştır. Müslümanlar, savaş sırasında değil, sonunda esir alma yoluna gitmişlerdir. ${ }^{14}$ Esir kelimesi, yalnızca savaştan sonra alınan kimseyi tanımlamak için kullanılmamıştır. Bir gemiden Müslüman sahillerine atılan, yolunu kaybeden veya kandırılıp alınan kimse ihtiyaten esir veya mülteci sayılmıştır. ${ }^{15}$

Sünnette, hicretin ilk on yılı içerisinde vuku bulan Dûmetü'l-Cendel ve Bedir muharebelerinde esir alındığına dair veriler bulunmuştur. Hatta Bedir esirlerinin arasında Hz. Muhammed'in amcası Abbas b. Abdülmüttalib'in (ö. 32/653) olduğu da rivayet edilmiştir. ${ }^{16}$

Daha önce uluslararası bir teamül olan esir alma konusu, 1899-1907 yıllarında kara savaşları kurallarına ilişkin imzalanan Lahey sözleşmelerinin eklerinin ikinci bölümü ve 1929'da esirlere karşı muamelelere ilişkin imzalanan Cenevre Sözleşmesi ile meşru sayılmıştır. ${ }^{17} 12$ Ağustos 1949'da savaş esirleri ile ilgili imzalanan Cenevre Sözleşmesi'nin birinci ve ikinci maddesine göre "taraf devletler sözleşme hükümlerine saygı göstereceğini ve aralarında bir savaş olduğunda içlerinden biri savaş durumunda olduğunu kabul etmese bile sözleşme hükümlerini yerine getireceğini taahhüt etmelidir. Ayrıca bir taraf devlet kısmen veya tamamen işgal edildiğinde işgale karşı silahla direnç göstermese bile sözleşme hükümleri uygulanmalıdır."18

1949'da imzalanan Cenevre Sözleşmesine 1977'de eklenen birinci protokole göre “Bir milletin ırkçılık, zulüm ve işgale karşı mücadelesi ve insani hak ve özgürlüklerini almak amacıyla çıkardığı

\footnotetext{
11 el-Mâverdî, el-Ahkâmu's-sultaniyyetu ve'l-velâyetü'd-diniyye, 167; Heyet, el-Mevsûatü'l-fikhiyye, 4/195; ez-Zühaylî, Âsâru'l-harbi fi'l-fikhi'l-íslâmî, 469 .

12Mahmûd Sâmî, Buhûs fi kânûni'l-harb (Kahire: Mektebü'l-bulâk, ts.), 210; ez-Zühaylî, Âsâru'l-harbi fi'l-fikhi'l-İslâmî, 429.

${ }^{13}$ Muhammed 47/4.

14 ez-Zühaylî, Âsâru'l-harbi fi'l-fikhi'l-íslâmî, 430.

${ }^{15}$ Ahmed b. Abdulhalim İbn Teymiyye, es-Siyâsiyyetu'ş-şeriyye, thk. Su' ûd el-Atişân (Şerhu'l-umde, 1413), 133.

${ }^{16}$ İbn Hişâm, es-Sîretü'n-nebeviyye, 2/5-45.

17 İttifâkiyâtu Cenif, md. 29, s. 63.

18 İttifâkiyâtu Cenif, md. 1-2, s. 13.
} 
silahlı çatışmalar uluslararası bakımdan meşrudur. Dolayısıyla bu tarafların birisi düşman tarafından ele geçirilince savaş esiri sayılacaktır." 19

\section{Esirlere Yönelik Muamele}

\section{1. İslam Hukukunda Esirlere Karşı Muamele}

İslam'a göre esir, savaş bittiğinde silahını bırakıp, teslim olmaya mecbur olarak barışı talep eden bir insandır. İslam, Müslümanların eline düşen esirler ile Müslümanların ilişkisini düzenleyecek kurallar koyarak savaşçıların intikam almak istemelerinden kaynaklanabilecek olumsuzlukları önlemek istemiştir. Bu bağlamda merhamet, adalet ve ihsan dini olma vasfını belirtmek üzere, esirlere önem vermeyi ve onlara iyi davranmayı emretmiş; esirleri işkenceye, eziyete, açlı̆̆a ve susuzluğa maruz bırakmayı veya çıplak bırakmayı haram kılmıştır. Esirlere ihsan eden ve merhametli bir şekilde davrananları övmüştür. ${ }^{20}$

Ebû Mûsâ'dan rivayet edildiğine göre, Rasûlullah (s.a.s.) şöyle buyurmuştur: “Esiri kurtarın, davet edene icabet edin, aç olanı doyurun ve hasta olanı ziyaret edin" ${ }^{21}$

Peygamberimiz (s.a.s.) Bedir esirleri hususunda şu emri salık vermiştir: “Esirlere karşı hayırhah olun." 22 Bu hadiste emir kullanıldığı için esirlere karşı hayırhah olmak mendub veya mübah değil de vacip olmaktadır.

Esirlere muamele konusunda İslam'ın yapılmasını emrettiği görevler ana hatlarıyla şunlardır:

Esirin Doyurulması: Kur'an-1 Kerim'de esirlere ihsan edenler övülerek şöyle buyrulmuştur: "Onlar, seve seve yiyeceği yoksula, yetime ve esire yedirirler." 23 İbn Kesir bu ayetin tefsirinde İbn Abbas'tan ayetin müşriklerle ilgili olduğuna dair bir görüş aktarmıştır: İbn Abbas'tan aktarılan rivayete göre Resulullah (s.a.s.) Bedir gününde esirlere ikram etmelerini buyurduğu için sahabeler esirlere yemek konusunda öncelik tanımışlardır. Mücahid, "sahabiler bu yemekleri sevdiği halde esirlere veriyorlard1." demiştir. ${ }^{24}$

Kurtubî de Abdullah b. Abbas'tan naklettiğine göre, Peygamberimizin (s.a.s.) sahabileri, ellerine düşen esirlere -müşrik olduğu halde diğer insanlarla eşit miktarda yemek vermişlerdir. Kurtubi'nin zikrettiği başka bir rivayette de "Müşrik esiri yedirmek, Allah katında bir yakınlıktır" denilmiştir. ${ }^{25}$

İslam'a göre esirin parası olmadığı ve zincirlenip çalışamadığı için onu yemekten mahrum bırakanlar, kıyamet gününde hesabı sorulacak büyük bir günah işlemişlerdir. Ayrıca ayete göre esir eden, yemeğin kalan kısmını değil de sevdiği ve ihtiyaç duyduğu halde yemeğin en iyisini esire vermelidir. Dolayısıyla esiri yemekten mahrum bırakmak bir günahtır. Ebû Mûsâ'dan rivayet edildiğine göre de Rasûlullah (s.a.s.) şöyle buyurdu: “Esiri kurtarın, davet edene cevap verin, aç olanı

\footnotetext{
19 İttifâkiyâtu Cenif, md. 93, s. 159.

${ }^{20}$ Seyid Sâbık, Fıkhu's-sünne (Beyrut: Daru'l-fikr, 1411), 2/686-687.

${ }^{21}$ Ebû Îsâ Muhammed b. Îsâ b. Sevre el-Buhârî, el-Câmi'u's-Sahîh, thk. Muhammed Züheyr Nasr (Dımaşk: Daru tavki'n-necât, 1422), "Cihâd", 193.

${ }^{22}$ Buhârî, "Cihâd", 11.

${ }^{23}$ el-İnsân 76/8.

${ }^{24}$ Ebü'l-Fidâ' İbn Kesîr, Tefsîru'l-Kur'âni'l-Azîm (Kahire: Matbaatü'l-istikâme, 1955), 14/210.

${ }^{25}$ Muhammed b. Ahmed Kurtubî, el-Câmi' li ahkâmi'l-Kur'ân (Kahire: Daru'l-kitâbi'l-Arabî, 1967), 17/129.
} 
doyurun ve hasta olanı ziyaret edin." 26 Savaş esirlerinden Amir b. Tufeyl27 yemek ve içmek hakkında sorduğunda Peygamberimiz "Evet bu senin ihtiyacındır- hakkındır" 28 diye cevap vermiştir .

Esirin Giydirilmesi: Esir, kendisini soğuk ve sıcaktan koruyacak bir kıyafetten mahrum bırakılmamalıdır. Cabir b. Abdullah'tan rivayet edildiğine göre, Bedir gününde Abbas da dahil omak üzere esirler götürüldügünde Abbas'ın üstünde bir kıyafet bulunmamıştır, Peygamberimiz (s.a.s.) ona bir gömlek aramıştır. Abdullah b. Übeyy'in gömleğini uygun görüp ona vermiştir. ${ }^{29}$

Peygamber efendimiz (s.a.s.), bir gazvede esir düşen Hatim et-Tai'nin kızına kıyafet ve nafaka vermiştir. ${ }^{30}$ Ayrıca Hz. Ali, esirlere birisi kışlık diğeri de yazlık olan iki kıyafet ayırmıştır. Kadı İmam Ebu Yusuf ise Harun Reşid'e birisi kalın ve kışlık diğeri de ince ve yazlık olmak üzere esirlere iki kıyafet ayrılmasını önermiştir. ${ }^{31}$

Esire İşkence Etmenin Yasaklanması: İslam, insan haysiyetine saygı göstermeyi ve iyi davranmayı vacip kılmıştır. Müslümanlar, ellerine düşen esirlere eziyet etmemelidir. Bedir gazvesinde Müslümanlar ellerine düşen Kureyşli bir köleyi bilgi almak amacıyla şiddetli bir şekilde dövüyorken Peygamberimiz (s.a.s.) namaz kılıyordu. Namazını bitirir bitirmez şöyle buyurmuştur: "Nefsim kudret eline olan Allah'a yemin ederim ki doğru söylediğinde dövüyorsunuz, yalan söylediğinde de bırakıyorsunuz." 32 Bu olay esirlere işkence etme ve vurmanın caiz olmadığını kanitlamaktadır.

Esiri Dininden Vazgeçmeye Zorlamanın Yasaklanması: Esir İslam’a girmeye zorlanmamalı, güzel öğütle davet edilmelidir. Şimdiki tabirle din özgürlüğü korunmuştur. Enfal Suresi'nde şöyle buyrulmuştur: “Ey Peygamber! Elinizdeki esirlere söyle: Eğer Allah kalplerinizde iman ,ihlas, iyi niyet gibi bir hayır olduğunu bilirse sizden alınan fidyeden daha hayırlısını size verir ve sizi bağışlar. Allah çok bağışlayandır, çok merhamet edendir." 33

$\mathrm{Bu}$ ayet esirleri İslam'a davet edip tevbe etsinler diye onlara yeni bir fırsat verdiği gibi İslam'a isteyerek girmeleri durumunda ödedikleri fidyenin telafi olacağını, dünya ve ahirette bol rızka sahip olacaklarını ve dine girmeden önce işledikleri günahların affedileceğini beyan etmiştir. Ayrıca Peygamberimiz'in birini İslam'a girmeye zorladığı görülmemiştir. Müslim ve Buhârî'nin Ebu Hureyre'den rivayet ettiğine göre Sümame b. Üsal el-Hanefi, Müslümanların eline düşen müşrik bir esir olup camide bağlanmış, Peygamberimiz de ona gelip "Ey Sümame! Neyin var?" diye sormuş, Sümame "Bende hayır var, beni öldürürsen bir insan öldürmüş olursun, serbest bırakıp nimet edersen de minnetkar birine ikram etmiş olursun, para istiyorsan istediğin kadarı söyle" diye cevap vermiştir.

Peygamberimiz onu kendi haline bırakmış, ertesi gün aynı sohbet tekrar edilmiş, üçüncü günde ise Peygamberimiz (Sümame'yi serbest bırakın) demiş, Sümame serbest olunca gusül alıp geri dönmüş ve “La ilahe İllallah Muhammedun Resulüllah, Ey Muhammed daha önce yüzün bu dünyada

\footnotetext{
${ }^{26}$ Buhârî, "Ehâdîsü'l-enbiyâ", 60. (No. 3482); Müslim, "Selâm”, 39. (No. 2242).

27 İbn Hacer Ebü'l-Fadl Ahmed b. Ali b. Muhammed b. Muhammed Askalânî, el-İsâbe fi temyîzi's-sahâbe (Misır: Matbaatü'ssa'âde, 1328), 125.

28 İbn Hişâm, es-Sîretü'n-nebeviyye, 4/683.

${ }^{29}$ İbn Hacer Ebü'l-Fadl Ahmed b. Ali b. Muhammed b. Muhammed Askalânî, Fethu'l-bârî fi şerhi Sahîhi'l-Buharî (Beyrut: Daru'lmarife, ts.), 6/167.

${ }^{30}$ el-Hisemî, Mecme' $\hat{u}^{\prime} z$-zevâid ve menbe'u'l-fevâid, 6/337.

${ }^{31}$ Ebû Yûsuf Ya'kûb b. İbrâhîm el-Kûfî, el-Harâc (Beyrut: Daru'l-marife, 1399), 152.

32 Ebû Dâvûd, "Cihâd", 85.

33 el-Enfâl 8/70.
} 
en nefret ettiğim yüzken bugün en sevdiğim yüz oldu, daha önce dinin dünyada en nefret ettiğim dinken bugün en sevdiğim din oldu, daha önce ülken dünyada en nefret ettiğim ülkeyken bugün en sevdiğim ülke oldu" ${ }^{\prime 3}$ demiştir. Böylelikle iyi ahlak ve davranışlar, sadece basit bir halktan kişileri değil, efendilerinden birinin kalbini çekip İslam'a korkarak değil de isteyerek girmesine neden olmuştur.

Esirin Kaldığı Mekan: Esirler uygun bir yerde kalmalıdır. Bu noktada en önemli olan husus, esirlere eziyet etmemek ve kaçmasına fırsat vermemektir.

Hz. Peygamber (s.a.s.) döneminde hapishane veya cezaevi olmadığı için esirler, haklarında bir karar verilene kadar camilerde veya Müslümanların evlerinde ayrı bir odada kalmıştır. Beyhaki'nin Zekvan'dan, onun da Hz. Âişe'den rivayet ettiğine göre Hz. Âişe'nin yanında misafirler varken Peygamberimiz (s.a.s.) onun evine bir esir bırakmış, Hz. Âişe misafirleriyle ilgilenirken esir kaçmıştır. Peygamberimiz (s.a.s.) gelip "Esir nerede?" diye sorunca Hz. Âişe "Misafirler beni meşgul etti" şeklinde cevap vermiştir. Hz. Peygamber, "Allah senin elini kessin” şeklinde bir karşılık vererek bazı adamları esiri bulmaya göndermiştir. Esir bulununca dönüp Hz. Âişe'nin elini uzattı̆̆ını görmüştür. “Neyin var?" diye sorunca Hz. Âişe "Ya Resulüllah! Siz Allah elimi kessin diye dua etmiştiniz. Ben de elimi kesecek birisini bekliyorum" diye cevap vermiştir. Peygamberimiz (s.a.s.) "Delirdin mi?" demiş, ellerini kaldırarak "Allah'ım! O'na kefaret ve temizlik ver" diye dua etmiştir. Zehebi'ye (ö. 748/1348) göre hadisin isnadı sahihtir. ${ }^{35}$ İbn Kesir (ö. 774/1373), Peygamberimiz'in (s.a.s.) Bedir esirlerini sahabeye dağıttığını söylemiştir. ${ }^{36}$

\subsection{Uluslararası Hukukta Esire Karşı Muamele}

Uluslararası hukuk, esirlere iyi bir şekilde davranmayı ve hayatlarını korumayı tavsiye etmiştir. Böylelikle 1949'da imzalanan Üçüncü Cenevre Sözleşmesinde savaş esirlerine dair kapsamlı olarak benimsenen sisteme göre aşağıda belirlenen haklar tanınmıştır:

İyi Davranılma Hakkı: Sözleşmeye göre, çatışmaya katılan bütün taraflar, savaş esirlerine her zaman insanca davranmayı taahhüt etmelidir. Ayrıca gayrimeşru ihmal nedeniyle veya herhangi bir sebeple esirin hayatını sonlandırabilecek bir tehlikeye sokmak yasaklandığı gibi esirin tedavisi gerektirmediği müddetçe vücudu üzerinde tıbbi deneyler yapmak da kanun dışıdır. ${ }^{37}$

Tıbbi Müdahale ve Sağlık Bakımı Hakkı: Sözleşmeye göre, esir eden devlet, esirlerin sağlık durumlarına uygun sağlık hizmetleri sunmalıdır. Dolayısıyla da tarafların her biri taşınabilir bir hastaneye sahip olmalıdır. ${ }^{38}$

Sığınak, Yemek ve Giyim Temini Hakkı: Sözleşmeye göre, esir eden devlet esirleri askerî kuvvetlerinin sığınak ve merkezine benzeyen ve ayn bölgede bulunan bir alana yerleştirmeli, esirlere yetecek kadar yemek ve kiyafet temin etmelidir. ${ }^{39}$

\footnotetext{
${ }^{34}$ Buhârî, "el-Megâzî”, 64.(No. 4372); Müslim, "Cihâd ve Siyer", 32. (No. 1764).

${ }^{35}$ Ebû Bekr Ahmed b. el-Hüseyn b. Alî Beyhakî, Esrâ, 89.

${ }^{36}$ Ebü'l-Fidâ' İbn Kesîr, el-Bidâye ve'n-nihâye (Beyrut: Mektebü'l-meârif, ts.), 5/191.

37 bk. İttifâkiyâtu Cenifi's-Salise", md. 13. s. 27.

${ }^{38}$ bk. İttifâkiyâtu Cenifi's-Salise", md. 15, s. 30.

${ }^{39}$ bk. İttifâkiyâtu Cenifi's-Salise", md. 1,30.
} 


\section{Esirlere Karşı Muamele Konusunda İslam Hukuku ile Uluslararası Hukukun Karşılaştırılması}

Esirlere karşı muameleye ilişkin uluslararası hukuk kurallarına baktığımızda İslam hukukunda geçen hükümlerden çok farkı olmadığını söyleyebiliriz. Üstelik sözleşmelerde geçen kanun ve hükümlerin çoğunlukla bin dörtyüz yıl önce konulan İslam hukuku kurallarından ilham alması muhtemeldir. Bu bağlamda İslam, esirleri maruz kalabileceği herhangi bir kötülükten koruyacak ve onlara saygı gösterecek insani kurallar koymaya öncü olmuştur. Uluslararası hukukta yazılanlar genelde uygulanmadığı için kağıt üstündeki ideal değerlerden ibaret kalmıştır. ${ }^{40}$

İslam hukukunun esirlerle ilgili hükümleri zorunlu yasa ve kanunlarla değil, Müslümanların kabulü ve tatbiki ile hayat bulmuştur. Çünkü İslam dini, bu dine mensup olanları, esirlere iyi davranmaya yönelten bir terbiyeye bağlı kılmıştır. Müslümanlar tarafından Peygamber'in emrini yerine getirerek esirlere iyi davranmak inanç kaynaklı bir ibadet ve Allah'ın katında bir yakınlık vesilesi olarak görülmüştür. Dolayısıyla düşmanlar Müslüman esirlere kötü davransalar bile mütakabiliyete riayet etmeyerek esir edilen gayrimüslimlere iyi davranmak gereklidir. ${ }^{41}$

Uluslararası sözleşmeler, sahada bilfiil uygulanmadığı için savaş esirlerini korumayı başaramamıştır. Her gün radyo, televizyon, dergi ve gazetelerin gösterdiği korkunç resimlere ve yayınladığı üzücü haberlere göre savaş esirlerinin acımasız bir şekilde vücut bütünlüğünü bozacak işlemlere tabi tutulduğunu üzülerek görmekteyiz. ${ }^{42}$

Sırp güçlerinin Bosna Hersek'te ve İsrail'in 1940'lardan beri Filistin'de yaptıkları, insan hakları kurallarına ve insanlığa bile aykırı olup uluslararası sözleşmelerin ihlaline dair örneklerdendir.

\section{4. İslam Hukuku Ve Uluslararası Hukuk Açısından Esirin Geleceği}

\section{1. İslam Hukukunda Esirlere Yapılabilecek İşlemler}

İslam'a göre esir, esasen öldürülmesi gereken bir düşman değil, Müslümanların bir misafiridir. İslam savaş tarihinin ilk gazvesi olan Bedir muharebesi, fıkhın teşri kaynaklarından biri sayılan Peygamberimizin (s.a.s.) emir ve hükümleriyle yönetildiği için fakihler savaş esirlerinin hükümlerini, Müslümanların Bedir esirlerine karşı muamelerinden çıkarmıştır.

Aşağıda esirlerle ilgili hükümler ve hakimin esirlere yapabilecekleri ile ilgili olarak İslam dini metinlerine dayalı biçimde fakihlerin görüşlerinden bahsedilecektir. Ardından günümüzde uluslararası hukuk bağlamında yerleşik kararlar sunulacaktır.

\subsubsection{Karşılıksız Olarak Salıverme (menn)}

"Menn" kelimesinin lügat manalarından biri, karşılığını beklemeden ihsan etmek ve bağışlamaktır. ${ }^{43}$ Istılah manası ise, esirlerin hiçbir bedel alınmaksızın dâru'l-harbe salınmasıdır. ${ }^{44}$ Menn'in caiz olup olmama hükmü konusunda fakihler iki gruba ayrılmışlardır: Birinci gruptaki

\footnotetext{
${ }^{40}$ bk. Tayyâr, Âdâbu'l-harb fi'l-fikhi'l-İslâmî, 85 .

${ }^{41}$ Muhammed Kemâleddin, el-Harb ve's-selâm fi'l-fikhi'd-düveli'l-İslâmî, 1399.

${ }^{42}$ Muhammed Ali Hasan, el-Alakâtü'd-düveliyyetü fi'l-Kur'ânî ve's-sünne, 224.

${ }^{43}$ Cemaleddin İbn Manzûr, Lisânü'l-Arab, thk. Abdusselam Muhammed Harun (Beyrut: Daru Sadır, 1993), 13/417.

${ }^{44}$ Ebü't-Tâhir Mecdüddîn el-Fîrûzâbâdî, el-Kâmûsü'l-muhît (Beyrut: Mektebetü't-türas fi müesseseti'r-risale, 1986), $13 / 417$.
} 
Hanefiler, ${ }^{45}$ Hz. Ömer (ö. 23/ 644), ${ }^{46}$ Atâ b. Ebû Rebâh (ö. 114/732), ve Mücâhid b. Cebr'e (ö. 103/721) göre menn caiz değildir. ${ }^{47}$

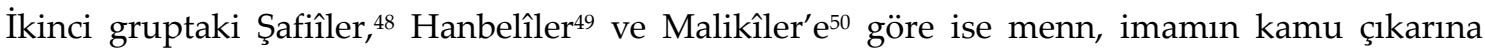
uygun görmesi şartıyla caizdir. Bununla birlikte İbn Abbas, İbn Ömer, ${ }^{51}$ Hasan-1 Basri ve Said b. Cübeyr'den de bu görüş rivayet edilmiştir. ${ }^{52}$ Şevkâni de cumhurun görüşü olduğunu vurgulayarak menn işini imamın izniyle kayıtlı değerlendiren kanaati tercih etmiştir. ${ }^{53}$

Karşılıksız olarak salıvermenin haram olduğuna hükmeden birinci görüşün delilleri iki kısma ayrilabilir:

\section{Mennin Haram Olduğuna Dair Hanefilerin ve Onlarla Aynı Fikirde Olanların Delilleri}

Kur'an-1 Kerim'den Deliller: "Müşrikleri bulduğunuz yerde öldürün” ayeti kerimesine ${ }^{54}$ göre, gerek savaşçı gerekse esir her kâfirin öldürülmesi vaciptir. Dolayısıyla karşılıksız olarak salıvermek caiz değildir." 55

Sünnet'ten Deliller: Abdullah b. Mesut'tan rivayet edildiğine göre Bedir gününde esirler toplandığında Resulullah (s.a.s.) şöyle buyurmuştur: "Fidye alınmadan ve boynu vurulmadan hiçbirisi serbest bırakılmasın." 56

Şevkâni bu hadisten yola çıkarak esirlerin ancak fidye verilerek serbest bırakılacağını veya öldürüleceğini, dolayısıyla da menn/karşılıksız salıverme işleminin caiz olmadığını söylemiştir. ${ }^{57}$

\section{Akli Deliller}

a. Salıvermekle esirin tekrar savaşa çıkması durumunda, müşrikleri güçlendirmiş ve Müslümanlara zarar vermiş oluruz. Dolayısıyla menn, elde edilen silahı kâfirlere geri vermek gibi olduğu için caiz değildir. ${ }^{58}$

b. Esir etmek mücahitlerin bir hakkıdır. Dolayısıyla tazminat vermeden bu hakkı iptal etmek caiz değildir..$^{59}$

c. İmamın esirlerin birisini karşılıksız olarak salıvermesi mantıklı değildir, hepsini salıvermek de mümkün değildir. Dolayısıyla karşılıksız salıvermenin yasaklanması en iyi yoldur. ${ }^{60}$

\footnotetext{
${ }^{45}$ Zeynüddîn İbn Nüceym, el-Bahrü'r-rấik, 5/901.

${ }^{46}$ Muhammed Ruvâs, Mevsû́atü fikhi Ömer b. Hattâb Kal'acî (Beyrut: 1981, ts.), 74.

${ }^{47}$ Muhammed b. Muhammed Ebü's-Su'ûd, Tefsiru İrşâdi akli's-selîm ilâ mezâyâi'l-Kur'âni'l-Kerîm, 124.

${ }^{48}$ Ebû İshak eş-Şîrâzî, el-Mühezzeb, ts., 2/236; Şemsüddîn Muhammed b. Ahmed el-Hatîb eş-Şirbînî, Mugni'l-muhtâc, 4/227.

${ }^{49}$ Mansûr b. Yûnus b. Salâhiddîn Buhûtî, Keşşâfü'l-kınấ alâ metni'l-İknấ' (Misır: el-Matbûatü'ş-şarkiyye, 1319), 3/47.

${ }^{50}$ Ebû Abdillâh Muhammed b. Abdillâh el-Huraşî, Hâşiyetü'l-Hurâşî alâ Muhtasari Halil (Beyrut: Daru'l-masâdır, 1587 ), 3/121.

${ }^{51}$ Kurtubî, el-Câmi' li ahkâmi'l-Kur'ân, 16/228.

52 Ebû Muhammed Muvaffakuddîn İbn Kudâme, eş-Şerhu'l-kebîr mea'l-mugnî (Beyrut: Daru'l-kitâbi'l-Arabî, 1403), $10 / 393$.

${ }^{53}$ Ebû Abdillâh eş-Şevkânî, es-Seylü'l-cerrâr el-mütedeffik alâ hadâikı'l-ezhâr (Beyrut: Daru'l-Kütübü'l-ïlmiyye, 1958 ), 568.

54 et-Tevbe $9 / 5$

${ }^{55}$ Ahmed b. Muhammed b. İsmail Tahtâvî, Haşiyetu't-Tahâvî, 2/447.

${ }^{56}$ Ebû Îsâ Muhammed b. Îsâ b. Sevre et-Tirmizî, Sünen-i Tirmizî, thk. Beşşar Avvad Maruf (Beyrut: Daru'l-Garbi'1-İslâmî, 1998).

“Tefsîru'l-Kur'ân”, 44. (No. 3084).

${ }^{57}$ eş-Şevkânî, es-Seylü'l-cerrâr el-mütedeffik alâ hadâikı'l-ezhâr, 8/148.

58 Serahsî, Şerhu's-Siyeri'l-Kebîr, 4/1031; Kemâlüddîn İbnü'l-Hümâm, Fethu'l-kadîr, ts., 5/60.

59 İbn Nüceym, el-Bahrü'r-râ'ik, 5/90.

${ }^{60}$ Serahsî, Şerhu's-Siyeri'l-Kebîr, 4/1031.
} 


\section{Mennin Caiz Olduğunu Savunan Hanefi İmam Muhammed b. Hasan'ın Delilleri}

Sünnet'ten Deliller: Resulullah (s.a.s.) Sümame b. Üsal el-Hanefi'yi Mekke'yi buğdaydan mahrum bırakmak şartıyla salıvermiştir. Sümame şartı gerçekleştirdiğinde Mekke insanları darlık çekmiştir. ${ }^{61}$

Kıyas: Cizye ve harac hususunda maslahat gereği bazı köleler karşılıksız olarak salıverilebilir. Buna dayanarak Müslümanların çıkarını gerçekleştirmek amacıyla bazı esirlerin karşılıksız olarak salıverilmesinin caiz olduğunu anlayabiliriz. ${ }^{62}$

\section{Karşılıksız Olarak Salıvermenin Caiz Olduğuna Hükmeden Görüşün Delilleri}

Kur'an-1 Kerim'den Deliller: “İnkâr edenlerle karşılaştığınız zaman (savaşta) boyunlarını vurun. Nihayet onları çökertip etkisiz hale getirdiğinizde bağı sıkı bağlayın (sağ kalanlarını esir alın). Artık bundan sonra (esirleri) ya karşılıksız ya da fidye karşılığı salıverin. Savaş sona erinceye kadar hüküm budur."63

Allah, ayette kullarını bazı konularda seçim yapmak konusunda serbest bırakmaktadır. Seçim, mantıken caiz şeyler arasında olacağından menn/salıverme ve fidye caizdir.

\section{Sünet'ten Deliller}

a. Sümame b. Üsal esir olarak götürülüp camide üç gün boyunca bağlı kaldıktan sonra Peygamberimiz (s.a.s.) onu karşılıksız olarak salıvermiştir. ${ }^{64}$

b. Resulullah (s.a.s.) Bedir esirleri hususunda şöyle buyurmuştur: “Mut'im b. 'Adiy hayatta olup benimle bu esirler hususunda konuşsaydı salıverirdim." 65 İbn Battal bu hadisle ilgili "Peygamberimiz (s.a.s.) caiz olmayan bir eylemle ilgili, şöyle olsaydı şöyle yapardım" demezdi. Dolayısıyla imamın fidye alınmaksızın esirleri salıvermesi caizdir" demiştir. ${ }^{66}$

c. Ebü'l-'Âs İbnü'r-Rebî'nin salıverilmesi: Hz.Âişe'den rivayet edildiğine göre Mekkeliler esirlerini fidye vermek için elçiler yolladığında Peygamberimizin (s.a.s.) kızı Zeynep de eşi Ebü'l-'Âs İbnü'r-Rebî'nin fidyesi için Hatice'nin ona verdiği kolyeyi gönderdi. Resulullah (s.a.s.) kolyeyi görünce çok üzülüp "İsterseniz esirini salıverip gönderdiğini geri verin" dedi. Sahabeler de "evet" dediler. Böylece Ebü'l-'Âs İbnü'r-Rebî'yi salıverip Zeynep'e gönderdiğini geri verdiler. ${ }^{67}$ Esirleri karşılıksız salıvermek caiz olmasaydı Peygamberimiz (s.a.s.) sahabelerinden bunu istemez ve salıvermelerini onaylamazdi.

d. Ebu İzze Şair el-Cümehî’nin salıverilmesi: Ebu İzze Bedir esirlerinden biriydi. Peygamberimize (s.a.s.) kızları olduğunu, kendisini salıvermesinin onlara bir sadaka olacağını söyleyince Peygambermiz (s.a.s.) kendisine karşı savaşmama sözüne karşılık onu salıvermişti. Ancak Ebu İzze sözünde durmayarak Uhut savaşına katılmış ve buradaesir düşmüştü. Tekrar salıverilmeyi

\footnotetext{
${ }^{61}$ Buhârî, “Magâzî”, 64. (No. 4114).

${ }^{62}$ Serahsî, Şerhu's-Siyeri'l-Kebîr, 4/1030.

${ }^{63}$ Muhammed 47/4.

64Buhârî, "Magâzî", 64. (No. 4114).

${ }^{65}$ Buhârî, "Magâzî", 64. (No. 4114).

${ }^{66}$ Askalânî, Fethu'l-bârî fi şerhi Sahîhi'l-Buharî, 6/243.

${ }^{67}$ Ebû Dâvûd, "Cihâd”, 62.
} 
istediyse de Peygamber efendimizin (s.a.s.) emri ile öldürülmüştür. ${ }^{68} \mathrm{Bu}$ olay da Hz. Peygamber'in (s.a.s.) bir esiri karşılıksız olarak salıverdiğine delildir.

e. Hudeybiye gününde bazı esirler salıverilmiştir: 69 Enes b. Malik'ten rivayet edildiğine göre, Tenim dağlarında kalan Resulullah (s.a.s.) ve sahabilerine sabah namazında öldürmek amacıyla seksen Mekkeli saldırmıştır. Peygamberimiz ise onları esir alıp salıvermiş, ardından da "Mekke'nin göbeğinde, onların ellerini sizden, sizin ellerinizi onlardan çekendir" ${ }^{\prime 70}$ ayeti indirilmiştir. ${ }^{71}$ Bu rivayet, seksen Mekkelinin karşılıksız salıverildiğini kanıtlamaktadır.

f. Beni Kurayza, Müslümanlarla savaştıktan sonra Peygamber onları salıvermiştir. Tekrar savaştıklarında ise bazılarını, Sa'd b. Muaz'ın verdiği hükmü uygulayarak öldürtmüş, bazılarını da serbest bırakmıştır. ${ }^{72}$ Sad d. Kays'tan rivayet edildiğine göre Peygamberimiz (s.a.s.), Kurayza esirlerinden biri olan Zübeyr b. Bata'yı ailesi ve parası ile salıvermiştir. ${ }^{73}$

g. Peygamberimiz (s.a.s.) Mekke'nin fethinde Mekke ahalisini salıvermiştir. Bu durum Mekke'nin savaşla fethedildiğini savunanların kanaatine göredir. ${ }^{74}$

h. Peygamberimiz'in (s.a.s.), kılıcını çekip onu öldürmek isteyen çöllü birini salıvermesi: Cabir'den rivayet edildiğine göre, "Resulullah (s.a.s.) ile Necd'e gazveye çıkmışlardır. Bir yerde konaklayıp kaylule yaptıklarında bir Bedevi Hz. Peygamber'in kılıcını alarak 'şimdi seni benden kim kurtaracak' demiştir. Hz. Peygamber (s.a.s.) 'Allah kurtaracak' cevabını vermiş ve onu etkisiz hale getirip esir almıştır. Ashabını yanına çağırarak olanları anlatmış ve şahsı serbest bırakmıştır." ${ }^{\prime 75}$ Hafız b. Hacer, İbn İshak'ın rivayetine göre, Resulullah (s.a.s.) Bedeviye "kalk, işine git" demiştir. Bu durum, Peygamberimiz 'in (s.a.s.) kâfirlerin İslam'a girmelerini istediğini göstermektedir. ${ }^{76}$

Görüşlerin delilleri değerlendirildiğinde; İmam'ın esirleri karşılıksız olarak salıvermesinin caiz olduğunu söyleyen cumhurun görüşünün Müslümanların çıkarlarını gerçekleştirebilme açısından daha uygun olduğu kanaatindeyiz. Zira cumhurun delilleri daha kuvvetlidir. "Menn" (karşılıksız olarak salıverme), esirin İslam'a girmesine neden olabilir. Çünkü kavminin efendisi olan Sümame b. Üsal karşılıksız olarak salıverildikten sonra İslam'ı kabul ettiğini ilan etmiş ve kavmini etkileyerek İslam'ın topyekün kabul edilmesine vesile olmuştur.

Esir edilen kavmin liderinin salıverilmesi kavmini de etkilemekte ve Müslümanlara karşı savaşma isteklerini ortadan kaldırabilmektedir. Menn, düşmanların korkmasına neden olabilir. Çünkü esir, kavmine dönüp Müslümanların gücü, cesareti ve iyi davranmasından bahsedebilir.

\subsubsection{Fidye}

Fidye, bir esir kurtarmak için para vermektir. ${ }^{77}$ Fidye ve müfada eş anlamlı olup esiri para veya başka bir esir karşılığında kurtarmak demektir.

\footnotetext{
68 İbn Hişâm, es-Sîretü'n-nebeviyye, 3/106.

${ }^{69}$ İbn Kayyim el-Cevziyye, Zâdü'l-meâd fî hedyi hayri'l-ibâd, 2/66.

${ }^{70}$ Fetih 48/24.

${ }^{71}$ Müslim, “Cihâd ve Siyer”, 32. (No. 4656).

72 Safiyurrahman el-Mübârek fûrî, er-Rahiku'l-mahtûm (Suudi Arabistan: Daru'l-müeyyidi's-Su'ûdiyye, 1996), 314.

${ }^{73}$ el-Hisemî, Mecme' $\hat{u}^{\prime} z$-zevâid ve menbe'u'l-fevâid, 5/335.

74 İbn Hişâm, es-Sîretü'n-nebeviyye, 4/54.

${ }^{75}$ Müslim, "Fazâil", 43.

${ }^{76}$ Askalânî, Fethu'l-bârî fi şerhi Sahîhi'l-Buharî, 7/427.

77 İbn Manzûr, Lisânü'l-Arab, 15/149.
} 
Istılah manası: Fakihler kelimenin ıstılah manasına detaylı olarak değinmemişler, fidyeden bahsedildiğinde "esiri para karşılığında veya başka esirle değiştirerek kurtarmaktır" tarifini benimsemişlerdir. ${ }^{78}$ Şevkânî, "fidye, para veya düşmanların bir esirini verip esirimizi kurtarmakla sınırlı değildir. Esiri kurtarmakla ilgili bütün fiiller fidye sayılmaktadır" demiştir.79

Esir Takası: Fakihler, esir değiş tokuşunun hükmü konusunda iki gruba ayrılmışlardır: Birinci gruba göre esir değiş tokuşu caiz değildir. Bu kanaat Ebu Hanife'nin görüşüdür. ${ }^{80}$ İkinci grup esir değiş tokuşunu caiz bulmuştur. Malikîler, ${ }^{81}$ Şafiîler, ${ }^{82}$ Hanbelîler $^{83}$, Zahirîler ${ }^{84}$ ve Şevkânî, esir takasını dinen doğru ve geçerli saymaktadır.

Hanefilerin Esir Takası Hususundaki Delilleri: Hanefîler, Ebu Hanife'nin bu husustaki görüşlerini şu şekilde temellendirmeye çalışmışlardır. ${ }^{85}$

Kur'an-1 Kerim'den Deliller: "Haram aylar çıkınca müşrikleri öldürün." 86 "Hiçbir fitne kalmayıncaya ve din tamamıyla Allah'a munhasır oluncaya dek savaşın onlarla." 87 "Vurun onların boyunlarına, vurun bütün parmaklarına." 88

$\mathrm{Bu}$ ayetlere göre müşrikler öldürülmelidir. Müşriklerin öldürülmesi meselesi esir değiş tokuşu ile çelişmektedir. Ayrıca bir farzı yerine getirebilmemiz mümkün iken bundan vazgeçmemiz caiz değildir. ${ }^{89}$ Hanefi fakihlerden Kasânî ayetler uyarınca müşriklerin öldürülmesinin farz olduğunu ancak İslam'a girmeleri ümit edilmesi durumunda bu farzı bırakmanın mümkün olacağını ifade etmiştir. Ona göre mübadele yapmakla değil esirleri köleleştirmekle İslam’ı kabul etme imkanları gerçekleştirilebilir..$^{90}$

İmam Muhammed b. Hasan'dan da “Esirler elimizde mağlup haldedir, onları mübadele yaparak serbest bırakmak ehl-i zimmetin serbest bırakılması gibidir, caiz değildir" şeklinde bir görüş nakledilmiştir. ${ }^{91}$

\section{Aklî Deliller}

a. Esir değiş tokuşu ile kafirlere yardım etmiş olunur. Onlara dönen esir yine bize karşı savaşacağı için savaşa girmesini önlemek Müslüman esiri kurtarmaktan daha önemlidir. Çünkü bir

\footnotetext{
${ }^{78}$ Alaeddin b. Ebi Bekr b. Mes'ûd el-Hanefî el-Kâsânî, Bedâi'u's-senâi' fi tertibi'ş-şerâi (Mısır: el-Matbaatü'l-cemâliyye, ts.), 2/119; Ebü'l-Velîd Muhammed İbn Rüşd, Bidayetü'l-müctehid (Sana As-Siddik, 2003), 1/382.

${ }^{79}$ Şevkânî, es-Seylü'l-cerrâr el-mütedeffik alâ hadâikı'l-ezhâr, 568.

${ }^{80}$ Ebû Bekr Şemsü'l-eimme Muhammed Serahsî, el-Mebsût (Beyrut: Daru'l-marife, 1406), 10/139.

${ }^{81}$ İbn Rüşd, Bidayetü'l-müctehid, 1/382.

${ }^{82}$ Şirbînî, Mugni'l-muhtâc, 4/227.

${ }^{83}$ Buhûtî, Keşşâfü'l-kınâ' alâ metni'l-İknâ', 3/47.

${ }^{84}$ Ebû Muhammed İbn Hazm, el-Mahallî bi'l-âsâr (Beyrut: Daru'l-kütübi'l-ilmiyye, ts.), 7/309.

85 Ebû Bekir er-Râzî el-Cessâs, Ahkâmu'l-Kur'ân, thk. Muhammed Sâdık el-Kamhâvî (Beyrut: Daru ihyai't-türasi'l-Arabî, 1405), 3/392; Serahsî, el-Mebsût, 1/39; İbnü'l-Hümâm, Fethu'l-kadîr, 5/474.

86 et-Tevbe $9 / 5,98$.

87 el-Enfâl 8/39.

88 el-Enfâl 8/12.

89 Ebü'l-Fazl Mecdüddîn Abdullâh b. Mahmûd b. Mevdûd el-Mevsılî, el-İhtiyâru li Talili'l-Muhtâr (Beyrut: Daru'l-kütübi'lilmiyye, 1996), 4/125; İ̉n Hişâm, es-Sîretü'n-nebeviyye, 4/1582.

${ }^{90}$ el-Kâsânî, Bedâi'u's-senâi' fi tertibi'ş-şerâi, 7/120.

${ }^{91}$ Serahsî, Şerhu's-Siyeri'l-Kebîr, 4/1587.
} 
Müslümanın düşman eline esir düşmesi Allah'tan gelen özel bir imtihandır, ancak onlara bir esiri yollamak dolaylı bir şekilde başımıza bela getireceği için caiz değildir. ${ }^{92}$

b. Kafirlerle savaşta mal ve can kaybı yaşanmaktadır. Dolayısıyla Müslüman esirleri kurtarmak için yitirilen mal ve canların önemsenmemesi caiz değildir. ${ }^{93}$

Cumhurun İleri Sürdükleri Deliller: Cumhur'un esir takası hususunda ileri sürdükleri delilleri şu şekilde sınıflandırmak mümkündür:

Kur'an-1 Kerim'den Deliller: Yüce Allah şöyle buyuruyor: "İnkâr edenlerle (savaşta) karşılaştığınız zaman boyunlarını vurun. Nihayet onları çökertip etkisiz hale getirdiğinizde bağı sıkı bağlayın (sağ kalanlarım esir alın). Artık bundan sonra (esirleri) ya karşılıksız ya da fidye karşılı̆̆ı salıverin. Savaş sona erinceye kadar hüküm budur." 94

$\mathrm{Bu}$ ayete göre, Yüce Allah, Müslümanların imamına menn ve fidye arasında seçme imkanı vermiştir. Böylesi bir imkanın verilmesi iki durumun da caiz olduğunu kanıtlamaktadır.

\section{Sünnetten Deliller}

a. İmran b. Husayn'dan rivayet edildiğine göre, Sakif ve Akil kabilesi müttefiklerdi, Sakif iki sahabe esir almıştı, sahabiler ise Akil'den bir esir almıştı. Sonra mübadele yapılarak iki sahabe kurtarıld1. ${ }^{95}$ Tirmizi'ye göre, "Peygamberimizin (s.a.s.) sahabileri dahil olmak üzere ilim ehli fetvalarında çoğunlukla bu hadise dayanmaktadır. ${ }^{96}$

b. Seleme b. El-Ekva yaşadığı bir olayı şöyle anlatmaktadır: “Fizara Gazvesi, Ebubekir'in liderliğindeydi. Su kaynağına bir saatlik mesafedeyken Ebubekir biraz durmamızı emretti, sonra saldırmaya başlayıp su kaynağına geldi ve orada kimilerini öldürüp kimilerini esir aldı. Bu arada bir grup insana bakıyordum, dağa benden daha önce gelecekler diye korktuğum için dağ ile aralarına bir ok attım. Oku gördüklerinde durdular. Onları Ebu Bekir'e götürdüm, aralarında Araplar arasındaki en güzel ve iyi kızlardan biri vardı, ona ilaveten Fizara kabilesinden gelen bir kadın mevcuttu. Ebu Bekir, kızı bana verdi. Medine'ye kızla geldik ama örtüsünü kaldırmadım, bu sırada Resulullah (s.a.s.) ile çarşıda karşılaştığımda bana, 'Ey Seleme! Genç kızı bana teslim et' dedi. 'Ya Resulallah! Vallahi beğendim, örtüsünü kaldırmadım' dedim. Ertesi gün yine de Resulullah (s.a.s.) 'Ey Seleme! Bana bayanı ver" dedi, 'Ey Resulullah! sizin olsun, hiçbir kıyafetini açmadım' dedim. Böylece Resulullah (s.a.s.) kadını alıp esir alınan Müslümanları kurtarmak için Mekke’ye geri gönderdi." ${ }^{97}$

c. İbn İshak'in rivayet ettiği hikayeye göre, Sa'd b. Numan, Bedir Muharebesinden sonra eşiyle umreye girmek üzere yola çıkmıştı. İkisi de yaşlılardı. Sad, Mekkeli Müşriklerden korkmuyordu. Çünkü Kureyş, umreye veya hacca çıkanlara zarar vermeyeceğine söz vermişti. Ancak Ebu Süfyan ona saldırıp Mekke'de hapse attı ve şöyle dedi: "Muhammed, Bedir'de esir düşen oğlum Amr b. Ebu Süfyan'ı bana göndermezse ben de onu gömdermem." Sa'd'ın kavmi olan Hazrec, Resulullah'a (s.a.s.) gidip Sa'd'ı kurtarmak için Amr b. Ebu Süfyan'ı geri vermesini rica ettiler, Peygamberimiz de (s.a.s.)

\footnotetext{
${ }_{92}^{2}$ Serahsî, el-Mebsût, 10/139; el-Mevsılî, el-i̇htiyâru li Talili'l-Muhtâr, 4/125.

${ }^{93}$ Serahsî, el-Mebsût, 10/139.

${ }^{94}$ Muhammed 47/4.

${ }^{95}$ Müslim, "Cihâd ve Siyer", 32.

${ }^{96}$ Muhammed b. Abdurrahman Mübârekpûrî, Tuhfetu'l-ahvezî b̂̀ şerhi Câmii't-Tirmizî̀ (Kahire: Matbaatü'l-medenî, 1976), 7/131.

${ }^{97}$ Müslim", Cihâd ve Siyer" , 32.
} 
istediklerini yapıp Ebu Süfyan'a oğlunu gönderdi, böylece Ebu Süfyan Sa'd b. Numan'ı serbest biraktı..$^{98}$

\section{Kiyas}

a. Müslüman esirleri, silah veya fidye karşılığında kurtarmak caiz olduğuna göre mübadele yaparak kurtarmak da caizdir. ${ }^{99}$

b. İmamın, Müslümanların çıkarını gerçekleştirmek için esirleri köleleştirmesi caizdir. Müslüman esirlerini kafirlerden kurtarmak ise esirlerden köle edinmekten daha faydalıdır. Dolayısıyla esir takası da caiz olmalıdır. ${ }^{100}$

\section{Aklî Deliller}

a. Mübadele ile serbest bıraktığımız esirlerin gelecekte bize karşı savaşacağı muhtemeldir ancak Müslüman esirlerin bize geri dönmesi muhakkaktır. Onların kurtuluşunun bize faydası vardır. ${ }^{101}$

b. Müslüman esirleri kafirlerden kurtarmak, kafiri öldürmek veya kullanmaktan daha önceliklidir. ${ }^{102}$

c. Müslüman esirleri müşriklerden kurtarmak vaciptir. Bu da ancak mübadele ile yapılabilir. Bu durumda müşrik esirleri öldürmekten vazgeçilmelidir. Dolayısıyla Müslümanların çıkarını gerçekleştirmek amacıyla tutukluların takas edilmesi caizdir. ${ }^{103}$

Ebû Yûsuf ve İmam Muhammed'in Görüşleri: Ebu Yusuf, aşağıda sunulan nedenlerle "Esir değiş tokuşu, esirler taksim edilmeden önce caizken taksim edildikten sonra caiz değildir." 104 demiştir.

1. Esirler taksim edilmeden önce bizden sayılmazlar. Taksim edildikten sonra ise öldürülmesi caiz olmadığı gibi mübadele yapmak amacıyla geri gönderilmesi de caiz değildir. İmam Ebu Yusuf "Savaş sona erinceye kadar"105ayetini taksimin kinayesi olarak saymaktadır. 106

2. Esirler taksim edildikten sonra, mübadele yapmak, esiri alanın mülkünü razı olmadan iptal etmek demektir. Dolayısıyla bu caiz değildir. Buna karşın, taksim edilmeden önce mülk yoktur, iptal edilebilir ve mütekarrir olmayan bir sabit hak vardır. ${ }^{107}$

İmam Muhammed b. Hasan aşağıdaki nedenlerle “Esir değiş tokuşu esirler taksimden önce de sonra da caizdir"108 demiştir:

1. Taksim edilmeden önce mübadele yapmak, Müslüman esirleri kafirlerden kurtarmak amacıyla caiz kılınmıştır. Taksim edildikten sonra da bu amaç gerçekleştirilebilmektedir. Ayrıca esirler taksim edildiğinde mal gibi değerlendirilir. Müslüman esirleri fidye karşılığında kurtarmak

\footnotetext{
98 İbn Hişâm, es-Sîretü'n-nebeviyye, 2/305.

${ }^{99}$ Serahsî, el-Mebsût, 10/139.

${ }^{100}$ Serahsî, Şerhu's-Siyeri'l-Kebîr, 4/1587.

101 el-Mevsılî, el-ïhtiyâru li Talili'l-Muhtâr, 4/124; el-Huraşî, Hâşiyetü'l-Hurâşî alâ Muhtasari Halil, 3/153.

102 Serahsî, el-Mebsût, 10/139; İbnü'1-Hümâm, Fethu'l-kadîr, 5/474.

103 Serahsî, Şerhu's-Siyeri'l-Kebîr, 4/1587.

104 el-Cessâs, Ahkâmu'l-Kur'ân, 3/392.

105 Muhammed 47/4.

106 Serahsî, el-Mebsût, 10/140.

107 el-Kâsânî, Bedâi'u's-senâi' fi tertibi'ş-şerâi', 7/128.

108 el-Cessâs, Ahkâmu'l-Kur'ân, 3/392; Serahsî, el-Mebsût, 10/140.
} 
caiz değil midir? Esirlerin taksim edildikten sonra mal hükmünde bulunması değiş tokuşun caiz olması ile çelişmemektedir. ${ }^{109}$

2. Esir alma hakkı taksimden önce de sabit bir haktır. Bu hak var olmasına rağmen taksimden önceki değiş tokuşu caiz kıldığımız gibi taksimden sonra mülk var olmasına rağmen değiş tokuşu caiz kılabilmekteyiz. ${ }^{110}$

\subsubsection{Esirlerin Öldürülmesi}

Dört mezhep, hakimin Müslümanların çıkarını gerçekleştirecek şekilde esirleri öldürmesinin caiz olduğu hususunda hemen hemen ittifak etmiştir. Ancak bazı alimler esirlerin öldürülmesinin yasak olduğunu söylemiştir.

Fakihler esirlerin öldürülmesinin hükmü konusunda iki gruba ayrılmıştır:

Hanefiler ${ }^{111}$, Malikiler ${ }^{112}$, Şafiler ${ }^{113}$, Hanbeliler ${ }^{114}$ Zahiriler $^{115}$, eş-Şevkânî116 ve Ebu Sevr' ${ }^{117}$ göre; imam, bu işin Müslümanların faydasına olacağını düşünüyorsa esirlerin öldürülmesi caizdir. Tirmizi de "Peygamberin sahabeleri de dahil olmak üzere ilim ehlinin çoğuna göre imam istediği esirleri öldürebilir" demiştir.118 el-Cessas da meseleye ilişkin şunları söylemiştir: "Mısırlı bazı fakihler esirin öldürülmesi hususunda ittifak sağlamıştır. Aralarında bir ihtilaf bulunmamaktadır. Peygamberimizden tevatür yoluyla nakledilen haberlere göre o da esirleri öldürtmüştür."119

Hasan-1 Basri, Ata ${ }^{120}$ Said b. Cübeyr ${ }^{121}$, Muhammed b. Sirin ${ }^{122}$ ve Hammad b. Ebi Süleyman'a ${ }^{123}$ göre ise, esirin öldürülmesi mekruhtur.

Esirin öldürülmesinin Caiz Olduğunu Söyleyenlerin Delilleri: Kur'an-ı Kerim'den Deliller: "Haram aylar çıkınca Allah'a ortak koşanları artık bulduğunuz yerde öldürün, onları yakalayıp hapsedin ve her gözetleme yerine oturup onları gözetleyin. Eğer tövbe ederler, namazı kılıp zekâtı da verirlerse, kendilerini serbest bırakın. Şüphesiz Allah çok bağışlayıcıdır, çok merhamet edicidir."124

İmam el-Aynî yukarıda sunulan ayet hakkında şu bilgileri sunmuştır: "Bu ayet geç dönemde indirilmiştir. Çünkü Tevbe Sûresi son zamanlarda vahyedilen surelerdendir. Her durumda

109 el-Cessâs, Ahkâmu'l-Kur'ân, 3/392; Serahsî, el-Mebsût, 10/140.

110 el-Kâsânî, Bedâi'u's-senâi' fi tertibi'ş-şerâi', 7/128.

111 Serahsî, el-Mebsût, 10/24; Muhammed Emîn İbn Âbidîn, Reddü'l-muhtâr ale'd-Dürri'l-muhtâr (Riyad: el-Mektebetü'tTedmiriyye, 1998), 4/139.

112 Ebu'l-Berekât Ahmed b. Muhammed b. Ahmed Derdîr, eş-Şerhu's-Sagîr alâ akrabi'l-mesâlik ilâ mezhebi'l-İmam Mâlik (Mısır: Daru'l-meârif, ts.), 2/296.

113 İbrahim b. Ali eş-Şirâzî, el-Mihzeb (Beyrut: Daru'l-fikr, 1975), 2/236; eş-Şirbînî, Mugni'l-muhtâc, 4/227.

114 İbrahim b. Muhammed İbn Müfellah, el-Furû' (Beyrut: Daru'l-kütübi'l-ilmiyye, 1418), 6/213; Buhûtî, Keşşâü̈l-kınâ' alâ metni'l-

$\dot{I} k n \hat{a}^{\prime}, 3 / 47$.

115 İbn Hazm, el-Mahallî bi'l-âsâr, 7/1296.

116 Ebû Abdillâh eş-Şevkânî, Nilü'l-evtâr, ts., 8/145.

117 Sadî Ali Hüseyin Ali Cebr, Fikhu'l-İmam Ebî Sevr (Ummân: Daru'l-furkân, 1983), 776.

118 Mübârekpûrî, Tuhfetu'l-ahvezî bî şerhi Câmii't-Tirmizî̀, 5/189.

119 el-Cessâs, Ahkâmu'l-Kur'ân, 3/361.

120 Serahsî, el-Mebsût, 10/24; Ebû Bekr b. Muhammed b. Abdullah İbnü'l-Arabî, Ahkamü'l-Kurân (Beyrut: Daru ihyai't-türasi'lArabî, 1200), 2/1703.

121 İbn Kudâme, eş-Şerhu'l-kebîr mea'l-mugnî, 10/394.

122 el-Cessâs, Ahkâmu'l-Kur'ân, 3/391.

${ }^{123}$ Serahsî, Şerhu's-Siyeri'l-Kebîr, 3/1024.

124 et-Tevbe $9 / 5$. 
öldürmenin vacip olduğunu "Müşrikleri öldürün" ayetiyle vurgulamıştır. Böylece ondan önceki ayetler neshedilmiş olmaktadır."125

"Vurun onların boyunlarına, vurun bütün parmaklarına."126 Kâsânî, "Bu esir aldıktan sonra olabilir, çünkü savaştayken boyunlara vurulamaz" demiştir. ${ }^{127}$

"Onları nerede yakalarsanız öldürün, sizi çıkardıkları yerden siz de onları çıkarın."128

İbnü'l-Arabî yukarıda sunulan ayet hakkında şunları söylemiştir: Bu ayet esirin öldürülmesinin hükmünü açıklayan belli bir delildir."129

"Yeryüzünde düşmanı tamamıyla sindirip hakim duruma gelmedikçe, hiçbir peygambere esir almak yakışmaz."130 Rivayetlere göre bu ayet ile Peygamberimize (s.a.s.), Bedir esirlerini öldürmeyi tercih eden Ömer b. Hattab'ın fikri yerine esirleri öldürmemeyi tercih eden Ebu Bekr'in fikrini uyguladığı için sitem edilmiştir. İbn Rüşd, Bidayetü'l müctehid adlı kitabında "bu ayetin indirilmesinin sebebi, Bedir esirleridir. Dolayısıyla öldürmenin köleleştirmekten daha iyi olduğunu kanıtlamaktadır"131 demiştir.

Sünnetten Deliller: Abdullah b. Mesud'dan nakledildiğine göre, Bedir gününde esirler götürüldüğünde Resulullah (s.a.s.) "fidye vermeden hiçkimse serbest bırakılmasın, fidye vermeyenler sağ bırakılmasın” buyurmuştur. Abdullah b. Mesud, "Ey Resulullah ! Süheyl b. Beyza hariç olsun, çünkü onun İslam'dan bahsettiğini duydum" demiştir. Peygamber efendimiz bir müddet sessiz kaldıktan sonra "Süheyl b. Beyza hariç olsun" demiştir. Bu olay üzerine "Yeryüzünde düşmanı tamamıyla sindirip hakim duruma gelmedikçe, hiçbir peygambere esir almak yakışmaz" ayeti indirilmiştir. ${ }^{132}$

Ali b. Ebu Talib'den rivayet edildiğine göre Resulullah (s.a.s.) Cebrail'in kendisine “Bedir esirleri hususunda onları öldürmekle, fidye vermek arasında seçme imkânı vermesini tavsiye ettiğini ve fidye vererek serbest kalan esirler ile seneye aynı sayıda kafirin öldürüleceğini bildirmiştir. ${ }^{133}$

Hz. Ömer'den rivayet edildiğine göre Hz. Peygamber (s.a.s.) Bedir esirleri hususunda onun ve Hz. Ebubekir'in fikrini almış, Ebubekir fidye vermelerini tercih ederken Hz. Ömer öldürülmelerini yeğlemiştir. Resulullah(s.a.s.) Ebu Bekir'in fikrini uygulamıştır. ${ }^{134}$

Bedir Muharebesi'nde esir edilen Ukbe b. Ebi Muayt, en-Nadr b. el-Haris ve Tueyme b. Udey öldürülmüştür. ${ }^{135}$

Uhud Savaşı Müşriklerden Ebu'1-İzze el-Cumehi, Bedir'de esir düştüğünde Peygamberimize (s.a.s.) “Ey Muhammed! Beş kızım var, beni serbest bırak da onlara sadaka olsun” demişti,

\footnotetext{
125 Ekmeleddin Muhammed b. Mahmud el-Bâburtî, Şerhu'l-'Inâye ala'l-Hidaye (Mısır: el-Matbaatü'l-emiriyyeti'l-kübrâ, 1315), $5 / 695$.

126 el-Enfâl 8/12.

127 el-Kâsânî, Bedâi' u's-senâi' fi tertibi'ş-şerâi, 2/119.

128 el-Bakara 2/191.

129 İbnü'l-Arabî, Ahkamü'l-Kurân, 1/106.

130 el-Enfâl 8/67.

131 İbn Rüşd, Bidayetü'l-müctehid, 1/382.

132 Tirmizî, “Tefsîru'l-Kur'ân”, 44. (No. 3084).

133 Tirmizî, “Tefsîru'l-Kur'ân”, 44. (No. 3045).

${ }^{134}$ Müslim, "Cihâd ve Siyer", 32.

135 Serahsî, el-Mebsût, 10/24.
} 
Peygamberimiz (s.a.s.) onun serbest bıraktığında Ebu'1 İzze, “sana karşı savaşmayacağımı söz veririm" demişti. Kureyş Uhud'a çıkınca Safvan b. Umiye, Ebu İzze'ye “bizimle savaşa gel” demiş, Ebu İzze ise "Muhammed'e ona karşı savaşmayacağıma dair söz verdim" demişti. Safvan, Ebu İzze öldürülürse kızlarını kendi kızları ile yetiştireceğine, sağ dönerse ona çok para vereceğine söz verdi. Ebu İzze, kabul edip savaşa çıktı. Uhud Savaşı sonunda Kureyş'ten alınan tek esirdi. "Zorladıkları için savaş çıktım, kızlarım var, beni salıver" diyen Ebu İzze'ye Peygamberimiz (s.a.s.) şöyle buyurmuştur: "Bana verdiğin söz nerede? Vallahi Mekke'ye gidip Muhammed'i iki defa kandırdım diyemezsin, ey Asim b. Sabit! Götürüp boyununu vur" demiştir. ${ }^{136}$

Ahzap olarak bilinen Hendek Savaşı'nda Peygamberimiz (s.a.s.), Sa'd b. Muaz'ın Beni Kureyza Yahudileri hususunda hükmetmesini uygun görmüş ve onu bu iş için hakim tayin etmiştir. Sa'd b. Muaz, Beni Kureyza Yahudileri hususunda savaşçılarının öldürülmesine ve çocuklarının esir alınmasına hükmetmiştir. ${ }^{137}$

Mekke'nin fethinde Peygamberimiz (s.a.s.) bazı Müşriklerin Kabe'nin örtüsüne tutunmuş olsa bile öldürülmesini emretmiştir. Hilal b. Hatıl, Makis b. Sababe, Abdullah b. Ebi's Serh ve El-Haris b. Nüfeyl onlardandır. ${ }^{138}$

Yukarıda zikrettiğimiz deliller, Müslümanların çıkarına uygun düştüğü durumlarda esirlerin öldürmesinin caiz olduğunu kanıtlamaktadır.

Aklî Deliller: Bazen esirlerin öldürülmesi, Müslümanların menfaatini gerçekleştirebilir. Çünkü öldürme cezası, özellikle de esir, kavminin efendilerinden biri ise ve Müslümanlara karşı bir tavrı varsa, fesadı kesin bir şekilde ortadan kaldırıp Müslümanların moralini yükselttiği gibi kafirlerin moralini bozmaktadır. Bu durumda imam, esiri öldürmelidir. Çünkü Müslümanları güçlendirip kafirleri bastırmak, Müslümanların liderinin temel vazifelerindendir. ${ }^{139}$

\section{Esirlerin Öldürülmesinin Mekruh Olduğunu Söyleyenlerin Delilleri}

Kur'an-1 Kerim'den Deliller: "İnkâr edenlerle karşılaştığınız zaman (savaşta) boyunlarını vurun. Nihayet onları çökertip etkisiz hale getirdiğinizde bă̆ı sıkı bağlayın (sağ kalanlarını esir alın). Artık bundan sonra (esirleri) ya karşılıksız ya da fidye karşılığı salıverin. Savaş sona erinceye kadar hüküm budur. "140

Ayetin delil getirilmesinin nedeni: Yüce Allah ayette "menn" ile "fidye" arasında seçme imkanı verip öldürmekten bahsetmemiştir. ${ }^{141}$ Cessâs'ın, Ahkamü'l-Kur'ân adlı kitabında rivayet ettiğine göre İbn Ömer'e önemli bir esir götürülüp öldürmesi istendiğinde kabul etmeyip "ya karşl1ıssı ya da fidye karşılığ1 salıverin" ayetini tilavet etmiştir. ${ }^{142}$

İbn Cerir ve İbn Merduye'nin Hasan'dan rivayet ettiğine göre; el-Haccac'a esirler götürülünce İbn Ömer'e, onları öldürsün diye, göndermiştir. İbn Ömer ise Allah bize öldürmeyi emretmeyip şöyle

\footnotetext{
136 İbn Hişâm, es-Sîretü'n-nebeviyye, 2/485.

137 Müslim, "Cihâd ve Siyer", 32.

138 el-Cessâs, Ahkâmu'l-Kur'ân, 3/391.

${ }^{139}$ Ebû Bekir b. Muhammed Şattâ Dimyâtî, İânetü't-tâlibîn (Beyrut: Daru'l-fikr, ts.), 4/201.

${ }^{140}$ Muhammed 47/4.

${ }^{141}$ Serahsî, Şerhu's-Siyeri'l-Kebîr, 3/1025; Fahreddin er-Râzî, et-Tefsirü'l-kebîr, (Kahire: el-Matbaatü'l-Mısriyye, 1356), 28/44.

${ }^{142}$ el-Cessâs, Ahkamü'l-Kurân, 3/391.
} 
buyurdu: "Nihayet onları çökertip etkisiz hale getirdiğinizde bă̆ı sıkı bağlayın (să̆ kalanlarını esir alın). Artık bundan sonra (esirleri) ya karşılıksız ya da fidye karşılığı salıverin" demiştir. ${ }^{143}$

İbn Abbas da bu ayeti esirlerin öldürülmesinin caiz olmamasına delil olarak kullanmıştır. ${ }^{144}$

Esirleri öldürmenin caiz olmadığını savunanlara göre ayette düşmanların öldürüleceği zaman bellidir. Ayete göre boyunları vurmak savaş sona erinceye kadar sürmelidir. Ancak kafirleri çökertip etkisiz hale getirdiğimizde bağı sıkı bağlamamız lazımdır. Buna göre imamın esirleri öldürmeye hakkı yoktur. ${ }^{145}$

Ata ve Dahhak'tan"146 rivayet edildiğine göre; "ya karşılıksız ya da fidye karşılığı salıverin"147 ayeti "Müşrikleri nerede yakalarsanız öldürün"148 ayetini neshetmiştir.

Bildiğimiz gibi, esirlerin öldürülmesi, savaşmasınlar diye mübah kılınmıştır. Bu da esir almak ve savaşı bitirmekle gerçekleştirilebilir. Dolayısıyla öldürmek bu durumda sadece Müslümanların hakkını iptal edecektir. Bu işlem de caiz değildir. ${ }^{149}$

Sünnetten Deliller: Hz. Peygamber, Bedir esirlerinin bazılarını karşılıksız olarak salıverdiği gibi bazılarını fidye karşılığında bırakmıştır. ${ }^{150}$

İcma: İbn Rüşd, Hasan b. Muhammed et-Temimi'ye atfen sahabenin, esirlerin öldürülmesinin mekruh olduğu hususunda icma ettiklerini zikretmiştir. ${ }^{151}$

Yukarıda da zikrettiğimiz üzere İslam alimleri esirlerin akıbetleri hususunda ihtilafa düşmüşlerdir. Günümüz uluslararası hukuk normları açısından; İslam ülkelerinin, savaş halinde oldukları ülkelerle savaş esirlerini öldürmemek üzere anlaşmaları faydalı olacaktır. Uluslararası hukuk esirlerin öldürülmesini tasvip etmemektedir. Bu bağlamda esirlerin öldürülmesine hükmetmek suretiyle uluslararası hukuka aykırı düşmemiz bize zarar verecektir. Çünkü bu durumda kan dökülmesini sever gibi bir görüntü arzedecek ve esirlerin öldürülmesinin Kur'an ve Sünnet ile farz kılındığı intibası vermiş olacağız. Oysa ki bu hususta İslam hukukunda iki farklı görüş ortaya çıkmıştır; birisine göre imam karar vermelidir. İkincisine göre ise öldürmek yasaktır. Bu da sahabelerden İbn Abbas ve ibn Ömer'in, tabiilerden de el-Hasan, el-Ata ve İbn Sirin'in, çağdaş alimlerden Karadavi'nin tercih ettiği görüştür. Yüce Allah şöyle buyurmuştur; "Seni ancak alemlere rahmet gönderdik." Ayrıca esirleri öldürmek İslam'dan nefret etmeye yol açabilirken menn ve fidye gibi daha merhametli yollar vardır. Dolayısıyla esirler hususunda verilen hükümler zamana uygun olacak şekilde değişebilmektedir. Ancak Peygamberimiz (s.a.s.), Ukbe b. Ebi Muayt’1 ve Beni Kureyza esirlerini öldürdüğüne göre, savaş suçluları bu hükümden hariç olup onların öldürülmesi caizdir.

\footnotetext{
${ }^{143}$ Muhammed b. Cerîr et-Taberî, Câmiu'l-beyân an te'vîli âyi'l-Kur'ân (Beyrut: Daru'l-kütübi'l-ilmiyye, 1992), 26/42; Ebü'l-Fazl Celâlüddîn Abdurrahmân es-Süyûtî, ed-Dürrü'l-mensûr fi't-tefsiri bi'l-me'sûr (Beyrut: Daru'l-fikr, ts.), 6/46; Şehâbeddin Mahmud el-Âlûsî, Rûhu'l-me' ânîfî tefsîri'l-Kur' âni'l-Azîm ve's-Seb' i'l-Mesânî (Beyrut: Daru ihyai't-türasi'l-Arabî, 1989), $26 / 40$.

${ }^{144}$ es-Süyûtî, ed-Dürrü'l-mensûr fi't-tefsiri bi'l-me'sûr, 6/46.

${ }^{145}$ Kurtubî, el-Câmi' li ahkâmi'l-Kur'ân, 26/226.

${ }^{146}$ Ebû Abdillâh eş-Şevkânî, Fethu'l-Kadîr (Beyrut-Dımaşk: Daru İbn Kesîr- Daru Kelimi't-Tayyib, 1414), 5/30.

147 Muhammed 47/4.

148 et-Tevbe $9 / 5$.

149 Serahsî, Şerhu's-Siyeri'l-Kebîr, 3/1025.

${ }^{150}$ Müslim, "Cihâd ve Siyer", 32.

151 İbn Rüşd, Bidayetü'l-müctehid, 1/383.
} 


\section{Uluslararası Anlaşmalar Açısından Esirin Kaderi}

Antik çağda savaş esirlerine son derece acımasız davranıldığını görmekteyiz. İlk dönemlerde önce esir hemen öldürülüyordu. Sonraları köleleştirilip zor ve ağır işlerde çalıştırılmaları tercih edilmiştir. Öldürmek yerine geliştirilen köleleştirme uygulaması binlerce yıl sürmüştür.

Yedinci yüzyılda savaş sırasında taraf devletler aralarında anlaşarak esir değiş tokuşu yapmaya başlamıştır. Fidye karşılığında veya mübadele ile salıverilmeyen esir, savaş sona erinceye kadar tutulmuştur. Ancak fidye karşılığında veya mübadele ile serbest bırakılmıştır. Esirler, uygun olmayan yerlere yerleştirilip kendilerine sert bir şekilde davranılmıştır. Ancak esirlerin durumu sekizinci yüzyılın sonunda gelişmeye başlamıştır. ${ }^{152}$

Kısaca antik çağda öldürülüp kılıçtan geçirilmek suretiyle tanrılara kurban sunulan esirler, sonraları esir edenin mülkü kabul edilip köleleştirilir ve satılır hale gelmiştir. Cahiliye döneminde Araplar, Pers ve Yunanlılar gibi komşu devletlerin geleneklerinden etkilenmiştir. Ancak İslam geldiğinde esirlere iyi davranılmaya başlanmıştır. ${ }^{153}$

Modern çağda ise savaş esirleri meselesine değinen uluslararası metinler, Lahey'de 1899'da belirlenen "Kara Savaşı Talimatnamesi" ve 1907'de yürürlüğe koyulan talimatnamenin 4-20 maddeleridir. 1929'da, "Kara Savaşı Talimatnamesi"nin birinci bölümünün ikinci kısmını kaldıran "Cenevre İkinci Sözleşmesi” imzalanmıştır. Bu ikinci sözleşme ise 12 Ağustos 1949'da imzalanan “Cenevre Üçüncü Sözleşmesi” ile yürürlükten kaldırılmıştır. ${ }^{154}$

Kara Savaşı Talimatnamesi'nin 4-20 maddeleri ile savaş esirleri meselesi yeni bir anlayış içine girmiştir. Buna göre, esir düşmek esirin şanssızlığından kaynaklandığı için ayıp değildir. Dolayısıyla savaş esiri, satılabilen bir köle veya suçlu sayılamaz. ${ }^{155}$

Lahey Kara Savaşı Talimatnamesi ve 1949'da imzalanan Cenevre Sözleşmesi'ne göre, esir almak düşmanı sindirmeyi amaçlar. Bu nedenle esirlerin öldürmemesi ve ceza verilmeksizin kendilerine iyi davranilmasi gerekmektedir. ${ }^{156}$

1949'da imzalanan Cenevre Üçüncü Sözleşmesi'nin 118. maddesine göre, Savaş esirleri, fiili düşmanlık (savaş) sona erdiğinde salıverilip memleketine geri gönderilmelidir. ${ }^{157} \mathrm{Bu}$ bağlamda esir eden devlet, esirlerin sayısı veya konumuna bakmaksızın esirlerini gecikmeden serbest bırakmalıdır. Ayrıca esir, esareti sırasında bir suç işleyip de ceza almazsa esir eden devlet yanında tutulmamalıdır. ${ }^{158}$

Cenevre sözleşmesinin 21. maddesine göre savaş esiri, esir eden devlete karşı savaşmayacağına söz verdiğinde devletin bu vaadi kabul etmesi durumunda serbest bırakılmalıdır. Aynı zamanda esir eden devlet, kendisini salıvermek için bu sözü vermesine esiri zorlama hakkı yoktur. ${ }^{159}$

1949'da imzalanan Cenevre Üçüncü Sözleşmesi esir değiş tokuşuna değinmemiştir. Bu nedenle uluslararası teamüllere göre esir değiş tokuşu, esaretten kurtulmak amaciyla taraf devletlerin savaş

\footnotetext{
152 Abdulkerîm Ferhân, Esru'l-harb iberu't-tarih (Beyrut: Daru't-talîa, 1979), 170.

153 ez-Zühaylî, Âsâru'l-harbi fi'l-fikhi'l-İslâmî, 404.

154 el-Hindî, Medâdiü'l-kânûni'd-düveli'l-âm fi's-silm ve'l-harb, 349.

155 el-Hindî, Medâdiü'l-kânûni'd-düveli'l-âm fi's-silm ve'l-harb, 349.

${ }^{156}$ Mansûr, eş-Şeriatu'l-İslamiyye ve'l-kânûnü'd-düvelü'l-âm, ts., 339.

157 bk. İttifâkiyâtu Cenif, md., 1949, s. 149.

158 Musaylihî, Esru'l-harb, ts., 84-85.

159 bk. İttifâkiyâtu Cenif, md., 1949, s. 104-105.
} 
sırasında veya sonrasında anlaşmasıyla gerçekleştirilmelidir. "Savaşan her iki devlet tarafından serbest bırakılacak esirlerin sayısı eşit veya askeri rütbesi aynı olmalıdır" gibi şartlar varsa "Mübadele Sözleşmesi"nde tarafların anlaştığ1 gibi belirlenmelidir. ${ }^{160}$ Ancak esir değiş tokuşu sözleşmeleri, herhangi bir uluslararası anlaşma gibi geçerliliği, tasarruf yetkisi, uygulayacağı taraf, uygulama biçimi ve açıklaması gibi farklı yanlarıyla anlaşmalara ilişkin uluslararası hukukun genel hükümlerine uymalıdır. Ayrıca esirler mübadele sözleşmesine uygun bir şekilde mümkün olduğunca en kısa zamanda ülkelerine geri gönderilmelidir. Genellikle geri gönderme süreci Kızılay veya Kızılhaç komiteleri tarafından yürütülmektedir. ${ }^{161}$ Taraf devletler bir anlaşma imzalamazsa, esirler ancak savaş sona erip barış antlaşması imzalandığında salıverilip ülkelerine geri gönderilmektedir. ${ }^{162}$ Taraf devletlerin aksine anlaşmaları müstesna, esir değiş tokuşu ile salıverilen esirler savaş sona erinceye kadar savaşmaya dönmemelidir. ${ }^{163}$

Esirlerin öldürülmesi ve kötü davranılmasına karşı çıkan bu uluslararası sözleşme ve anlaşmalara rağmen büyük devletlerin umursamaz tavırlarından dolayı bu sözleşmeler uygulanmamaktadır. Gazete ve haber ajanslarının yayınladığı gibi, ABD, Guantanamo'daki esirlere pek uygun olmayan bir biçimde yaklaşmıştır. Amerikalılar, kimi esirlerin ve mahkumların el ve ayaklarını zincirleyerek, göz ve kulaklarını kapatarak, onları dünyadan tamamen soyutlayarak Küba'ya götürmüştür. ${ }^{164}$ Ebu Gureyb Hapishanesi'nde de Amerikalı subay ve askerler, Amerika'nın imzaladığı uluslararası sözleşmelere uymayıp Iraklı esirleri işkenceye maruz bırakmıştır. ${ }^{165}$

\subsection{Esirin Kaderi Konusunda İslam Hukuku ile Uluslararası Hukukun Karşılaştırılması}

Modern çağda uluslararası hukukun esirlerle ilgili koyduğu kurallar ve yürürlüğe koyduğu sözleşmeler İslam hukukunda geçen "menn" ve "fidye" hükümleri ile paralel niteliktedir. Uluslarası hukuk esirin öldürülmesi konusuna değinmemiş olsa bile esirin aleyhine bir hüküm çıarılması halinde ölüm cezası da dahil olmak üzere ceza uygulanmasına onay vermiştir. 1949'da imzalanan Cenevre Üçüncü Sözleşmesi'nin 85. maddesine göre, “Esirler, esir alınmadan önce işledikleri bir suçtan dolayı esir eden devlet tarafından mahkemeye getirilip ceza verilebilir." Dolayısıyla esirlere, esir alınmadan işlediği bir suçtan dolayı mahkemeye getirip ölüm cezası bile vermek yasak değildir. Ayrıca süper güçlere göre, mağlup devletin direnmesi durumunda esirleri öldürmek siyaset esaslarından biri sayılmaktadır. İşgalci devletler, işgal ettiği devlette bir direnç veya devrim çıkacağını öngörürse evleri yıkıp, insanları masum veya ayaklanmasına bakmaksızın öldürdüğü gibi kadın ve çocukları öldürmekten çekinmemektedir. İslam, merhamet ve adalet dini olarak, bu acımasız eylemleri mübah kılmamaktadır. Esirin öldürülmesi konusunda ise ihtilaf vardır. İbn Abbas, İbn Ömer, Hasan-1 Basri, el-Ata, ibn Sirin ve eş-Şuaybi gibi birçok sahabe ve âlim öldürmenin caiz olmadığını ileri sürmüştür. Hz. Peygamber (s.a.s.) döneminde esirlerin öldürülmeleri ise yalnızca savaş esiri olduğu için değil de esir alınmadan önce bir suç işlediği için bir ceza karşılığında ve nadiren vaki olmuştur.

Kısaca, uluslararası toplumun esire iyi davranılması konusunda koyduğu uluslararası hukuk kurallarının en iyisi olan 1899'da ve 1907'de imzalanan Lahey ve 1929 ve 1949'da imzalanan Cenevre

\footnotetext{
${ }^{160}$ Musaylihî, Esru'l-harb, 85-86.

${ }^{161}$ Ali Sadık Ebû Hayf, el-Kânûnü'd-düvelü'l-âlem (İskenderiyye: Minşaetü'l-Mearif, 1975), 821.

162 Ebû Hayf, el-Kânûnü'd-düvelü'l-âlem, 821.

163 Yûsuf el-Karadâvî, Fikhu'l-cihâd (Kahire: Mektebetü vehbe, 2000), 840.

164 el-Karadâvî, Fıkhu'l-cihâd, 840.

165 bk. İttifâkiyâtu Cenif, md., 1949, s. 135.
} 
Sözleşmelerinde ortaya konan prensipler, İslam dininin esirlere yaklaşımı ile tam bir uyum arzetmiştir. Çünkü İslam ilkeleri, insan hayatını ve haysiyetini korumak temelinde geliştirilmiştir. Bu bağlamda, yüce Allah'ın "Seni ancak alemlere rahmet olarak gönderdik"166 buyruğu ışı̆̆ında İslam hukukunun esirlere iyi muamele edilmesi hususundaki düzenlemelere çok daha erken başladığını söylemek yanlış olmayabilecektir.

\section{Sonuç}

İslam hukuku esirlere insani haklarını vermede öncü olmuştur. Esirlere iyi bir şekilde davranılmalı, temiz yerlere yerleştirilmeli, giyecek, yiyecek ve içecek esirgenmemeli, onlar hiçbir nedenle açlığa veya susuzluğa maruz bırakılmamalıdır. Esirler öldürülmemelidir. Çünkü İslam hukukunun, esirler hususunda merhamet, yardımseverlik ve adaleti salık veren hükümleri vardır. Dolayısıyla esirleri öldürüp İslam'dan nefret ettirmemek esas alınmalıdır. İslam'ın emretmediği öldürme fiilini aciz, savunmasız esirlere reva görülmemesi kanaatini yeğlemekteyiz. Bu kanaat ayrıca uluslararası hukuka daha uygundur. İslam hukuku kuralları, karşılıksız veya fidye karşılığında esirleri salıvermeyi de mubah kılmıştır. İbn Abbas ve İbn Ömer gibi ilk dönem fakihleri başta olmak üzere, birçok fakih, esirlerin öldürmemesi kanaatini tercih etmiştir.

İslam hukukuna göre esirler fidye karşılığında veya karşılıksız olarak salıverebildiği gibi esir değiş tokuşu ile de salıverilebilirler. Antik çağda esirlere sert ve kötü bir şekilde davranılmıştır. İslam öncesinde esirler boğazlanıp tanrılara kurban olarak sunulmuştur. Sonra da köle olarak satın alınmıştır. Diğer taraftan Pers ve Yunanlılar de esirlerine acımasızca davranıyorlardı. Araplar da Cahiliye döneminde komşularının alışkanlıklarından etkilenmiştir. Modern uluslararası hukukun esirler ve mübadele konusunda koyduğu hüküm ve kanunlar çoğunlukla on dört asır önce oluşan İslam hukuku kurallarından etkilenmiştir. Ancak günümüzde uluslararası hukuk kuralları tam olarak uygulanmamaktadir.

\section{Kaynakça}

Âlûsî, Şehâbeddin Mahmud. Rûhu'l-me ânî fî tefsîri'l-Kur' âni'l-Azîm ve's-Seb' i'l-Mesânî. Beyrut: Daru İhyai't-Türasi'l-Arabî, 4. Basım, 1989.

Askalânî, İbn Hacer Ebü'l-Fadl Ahmed b. Ali b. Muhammed b. Muhammed. Fethu'l-bârî fi şerhi Sahîhi'l-Buharî. Beyrut: Daru'l-Marife, ts.

Askalânî, İbn Hacer Ebü'l-Fadl Ahmed b. Ali b. Muhammed b. Muhammed. el-İsâbe fi temyîzi's-sahâbe. 3 Cilt. Mısır: Matbaatü's-Sa'âde, 1328.

Bâburtî, Ekmeleddin Muhammed b. Mahmud. Şerhu'l-'Inâye ala'l-Hidaye. Misır: el-Matbaatü'lEmiriyyeti'l-Kübrâ, 1315.

Beyhakî, Ebû Bekr Ahmed b. el-Hüseyn b. Alî. Esrâ, ts.

Buhârî, Ebû Îsâ Muhammed b. Îsâ b. Sevre. el-Câmi'u's-Sahîh. thk. Muhammed Züheyr Nasr. 9 Cilt. Dımaşk: Daru Tavki'n-Necât, 1. Basım, 1422.

166 el-Enbiyâ 21/107. 
Buhûtî, Mansûr b. Yûnus b. Salâhiddîn. Keşşâfü'l-kınâ' alâ metni'l-iknâa'. Mısır: el-Matbûatü'ş-Şarkiyye, 1319.

Cebr, Sadî Ali Hüseyin Ali. Fikhu'l-İmam Ebî Sevr. Ummân: Daru'l-Furkân, 1983.

Cessâs, Ebû Bekir er-Râzî. Ahkâmu'l-Kur'ân. thk. Muhammed Sâdık el-Kamhâvî. 5 Cilt. Beyrut: Daru İhyai't-Türasi'1-Arabî, 1405.

Cevziyye, İbn Kayyim. Zâdü'l-meâd fî hedyi hayri'l-ibâd, ts.

Derdîr, Ebu'l-Berekât Ahmed b. Muhammed b. Ahmed. eş-Şerhu's-Sagîr alâ akrabi'l-mesâlik ilâ mezhebi'lİmam Mâlik. Misır: Daru'l-Meârif, ts.

Dimyâtî, Ebû Bekir b. Muhammed Şattâ. İânetü't-tâlibîn. Beyrut: Daru'l-Fikr, ts.

Ebû Hayf, Ali Sadık. el-Kânûnü'd-düvelü'l-âlem. İskenderiyye: Minşaetü'l-Mearif, 1. Basım, 1975.

Ebü's-Su'ûd, Muhammed b. Muhammed. Tefsiru İş̧âdi akli's-selîm ilâ mezâyâa'l-Kur'âni'l-Kerîm, ts.

Ferhân, Abdulkerîm. Esru'l-harb iberu't-tarih. Beyrut: Daru't-Talîa, 1979.

Fîrûzâbâdî, Ebü't-Tâhir Mecdüddîn. el-Kâmûsü'l-muhît. Beyrut: Mektebetü't-Türas fi müesseseti'rrisale, 1986.

Hasan, Muhammed Ali. el-Alakâtü'd-düveliyyetü fi'l-Kur'ânî ve's-sünne, ts.

Heyet. el-Mevsûatü'l-fikhiyye. Kuveyt: Evkafu'l-Kuveyt, ts.

Heysemî, Alî b. Ebî Bekr. Mecme' û'z-zevâid ve menbe'u'l-fevâid. Beyrut: Daru'l-kitâbi'l-Arabî, 1. Basım, 1402.

Hindî. Medâdiü'l-kânûni'd-düveli'l-âm fi's-silm ve'l-harb, ts.

Huraşî, Ebû Abdillâh Muhammed b. Abdillâh. Hâşiyetü'l-Hurâşî alâ Muhtasari Halil. Beyrut: Daru'lmasâdır, 1587.

İbn Âbidîn, Muhammed Emîn. Reddü'l-muhtâr ale'd-Dürri'l-muhtâr. Riyad: el-Mektebetü't-Tedmüriyye, 1998.

İbn Hazm, Ebû Muhammed. el-Mahallî bi'l-âsâr. Beyrut: Daru'l-Kütübi'l-i̇lmiyye, ts.

İbn Hişâm, Ebû Muhammed Cemâlüddîn. es-Sîretü'n-nebeviyye. thk. Mustafa es-Sakâ - İbrahim elEybârî. Beyrut: Daru'l-Hayr, 1. Basım, 1996.

İbn Kesîr, Ebü'l-Fidâ'. el-Bidâye ve'n-nihâye. Beyrut: Mektebü'l-Meârif, ts.

İbn Kesîr, Tefsîru'l-Kur'âni'l-Azîm. Kahire: Matbaatü'l-istikâme, 3. Basım, 1955.

İbn Kudâme, Ebû Muhammed Muvaffakuddîn. eş-Şerhu'l-kebîr mea'l-mugnî. Beyrut: Daru'l-Kitâbi'lArabî, 1403.

İbn Manzûr, Cemaleddin. Lisânü'l-Arab. thk. Abdusselam Muhammed Harun. 15 Cilt. Beyrut: Daru Sadır, 3. Basım, 1993.

İbn Müfellah, İbrahim b. Muhammed. el-Furû'. Beyrut: Daru'1-Kütübi'1-İlmiyye, 1418.

İbn Nüceym, Zeynüddîn. el-Bahrü'r-râ'ik, ts.

İbn Rüşd, Ebü'l-Velîd Muhammed. Bidayetü'l-müctehid. Sana As-Siddik, 2003. 
İbn Teymiyye, Ahmed b. Abdulhalim. es-Siyâsiyyetu'ş-şeriyye. thk. Su'ûd el-Atişân. Şerhu'l-umde, 1413.

İbnü'l-Arabî, Ebû Bekr b. Muhammed b. Abdullah. Ahkamü'l-Kurân. Beyrut: Daru İhyai't-Türasi'1Arabî, 1. Basım, 1200.

İbnü'l-Hümâm, Kemâlüddîn. Fethu'l-Kadîr, ts.

Karadâvî, Yûsuf. Fıkhu'l-cihâd. Kahire: Mektebetü Vehbe, 2000.

Kâsânî, Alaeddin b. Ebi Bekr b. Mes'ûd el-Hanefî. Bedâi'u's-senâi' fi tertibi'ş-şerâi. Mısır: el-Matbaatü'lCemâliyye, 1. Basım, ts.

Kemâleddin, Muhammed. el-Harb ve's-selâm fi'l-fikhi'd-düveli'l-i̇slâmî, ts.

Kûfî, Ebû Yûsuf Ya'kûb b. İbrâhîm. el-Harâc. Beyrut: Daru'l-Marife, 1399.

Kurtubî, Muhammed b. Ahmed. el-Câmi' li ahkâmi'l-Kur'ân. Kahire: Daru'l-Kitâbi'l-Arabî, 1967.

Mansûr. eş-Şeriatu'l-İslamiyye ve'l-kânûnü'd-düvelü'l-âm, ts.

Mâverdî, Ebü'l-Hasen Alî b. Muhammed b. Habîb. el-Ahkâmu's-sultaniyyetu ve'l-velâyetü'd-diniyye. Mısır: Mustafa'l-Babî'l-Halabî, 1. Basım, ts.

Mevsılî, Ebü'l-Fazl Mecdüddîn Abdullâh b. Mahmûd b. Mevdûd. el-İhtiyâru li Talili'l-Muhtâr. Beyrut: Daru'1-Kütübi'l-İlmiyye, 1. Basım, 1996.

Musaylihî. Esra'l-harb, ts.

Mübârekfûrî, Safiyurrahman. er-Rahiku'l-mahtûm. Suudi Arabistan: Daru'l-müeyyidi's-Su'ûdiyye, 1. Basım, 1996.

Mübârekpûrî, Muhammed b. Abdurrahman. Tuhfetu'l-ahvezî bî şerhi Câmii't-Tirmizî. Kahire: Matbaatü'1-Medenî, 2. Basım, 1976.

Müslim el-Haccâc, Ebu'l-Huseyin. Sahih-i Müslim. thk. Muhammed Fuad Abdulbâkî. 5 Cilt. Beyrut: Daru İhyai't-Türasi'l-Arabî, ts.

Râzî, Fahreddin. et-Tefsirü'l-kebîr, Kahire: el-Matbaatü'l-Mısriyye, 1356.

Ruvâs, Muhammed. Mevsû́atü fikhi Ömer b. Hattâb Kal'acî. Beyrut: 1981, ts.

Sâbık, Seyid. Fıkhu's-sünne. Beyrut: Daru'1-fikr, 1. Basım, 1411.

Sâmî, Mahmûd. Buhûs fi kânûni'l-harb. Kahire: Mektebü'l-Bulâk, ts.

Serahsî, Ebû Bekr Şemsü'l-eimme Muhammed. el-Mebsût. Beyrut: Daru'1-Marife, 1406.

Serahsî, Ebû Bekr Şemsü'l-eimme Muhammed. Şerhu's-Siyeri'l-Kebîr. Mısır: Matbaatu şirketi'l-ilânâti'şşarkiyye, ts.

Serahsî, Sicistânî, Ebu Davud es-. Sünen-i Ebu Davud. thk. Muhammed Muhyiddin Abdulhamid. 4 Cilt. Beyrut: el-Mektebetü'l-Asriyye, ts.

Süyûtî, Ebü'l-Fazl Celâlüddîn Abdurrahmân. ed-Dürrü'l-mensûr fi't-tefsiri bi'l-me'sûr. Beyrut: Daru'lfikr, ts.

Şevkânî , Ebû Abdillâh. Neylü'l-evtâr, ts. 
Şevkânî, Ebû Abdillâh. es-Seylü'l-cerrâr el-mütedeffik alâ hadâikı'l-ezhâr. Beyrut: Daru'l-kütübü'l-ilmiyye, 1. Basım, 1958.

Şevkânî, Ebû Abdillâh. Fethu'l-Kadîr. 6 Cilt. Beyrut-Dımaşk: Daru İbn Kesîr- Daru Kelimi't-Tayyib, 1. Basım, 1414.

Şîrâzî, Ebû İshak. el-Mühezzeb, ts.

Şirâzî, İbrahim b. Ali. el-Mihzeb. Beyrut: Daru'l-Fikr, 1975.

Şirbînî, Şemsüddîn Muhammed b. Ahmed el-Hatîb. Mugni'l-muhtâc, ts.

Taberî, Muhammed b. Cerîr. Câmiu'l-beyân an te'vîli âyi'l-Kur'ân. Beyrut: Daru'l-Kütübi'l-İlmiyye, 1. Basım, 1992.

Tahtâvî, Ahmed b. Muhammed b. İsmail. Haşiyetu't-Tahâvô, ts.

Tayyâr, Ali. Âdâbu'l-harb fi'l-fikhi'l-İslâmî. Riyad: Mektebetü'l-Melik Fehd, 2008.

Tirmizî, Ebû Îsâ Muhammed b. Îsâ b. Sevre. Sünen-i Tirmizî. thk. Beşşar Avvad Maruf. 6 Cilt. Beyrut: Daru'l-Garbi'1-İslâmî, 1998.

Yusuf el-Far, Abdulvahid Muhammed. Esru'l-harb. Kahire: Alemü'l-Kütübi'l-Kâhire, 1975.

Zühaylî, Vehbe. Âsâru'l-harbi fi'l-fikhi'l-İslâmî. Dımaşk: Daru'l-Fikr, 1. Basım, 1998. 